\title{
Mustafa Eyyûbîzâde (Ejubović) el-Mostarî'nin Eserlerinin İncelenmesi ve Arap Dili ve Belagatına Dair Üç Risalesinin Tahkiki
}

\author{
Dr. Mesut Köksoy \\ Selçuk Üniversitesi, Edebiyat Fakültesi \\ Arap Dili ve Edebiyatı Bölümü \\ mkoksoy@selcuk.edu.tr
}

Öz

Osmanlı döneminin en önde gelen Bosnalı âlimlerinden birisi yüksek eğitimini İstanbul'da almış ve otuzdan fazla eser te'lif etmiş Şeyh Yuyo (Šejh Jujo) lakaplı Mustafa b. Yusuf b. Murad Eyyûbîzâde (Ejubović) el-Mostarî (ö. 1119/1707)'dir. Bu çalışmada Eyyûbîzâde'nin hayatı ile bilgilerin yanı sıra kendisi ve öğrencisi İbrahim Opijač elMostarî́nin verdiği bilgiler, kütüphanelerden temin edilen nüshalar, kütüphane katalogları ile diğer kaynaklardaki bilgiler karşılaştırılarak Eyyûbîzâde'ye ait olan eserler ve eserlerin çeşitli kütüphanelerde bulunan yazma nüshalarına dair detaylı bir inceleme yapılmıştır. $\mathrm{Bu}$ sayede Eyyûbîzâde'nin eserleri ve eserlerinin nüshalarına dair kaynaklardaki eksiklik ve yanlışlıklar tespit edilerek düzeltilmiştir. Ayrıca bu çalışmada Eyyûbîzâde'nin Arap dili ve belagatına dair az hacimli üç risalesinin incelemesi yapılarak tahkikli metinleri verilmiştir. Risâle fì Beyâni İctimâ 'i'l-İstiâreti'l-Tebeiyye me 'a't-Temsîliyye adlı ilk risale, et-Teftâzânî ve esSeyyid eş-Şerîf el-Curcânî arasında Emir Timur'un sarayında gerçekleşen meşhur münazaranın konusu olan Bakara suresi 5. ayette istiâre-i temsiliyye ve istiâre-i tebeiyyenin bir arada bulunup bulunamayacağına dair ihtilaf hakkındadır. Risâle fi Kevni'l-Cumle Mutlakan Haberan li'l-Mubteda' adlı ikinci risale, et-Teftâzânî ve es-Seyyid eş-Şerîf el-Curcânî arasındaki ihtilaflardan bir diğeri olan inşâ cümlesinin te'vil olmadan haber olup olamayacağına dair ihtilaf hakkındadır. Risâle fì mâ Kâle el-Kuhistânî an İrâbi İbareti "Kitâbi'tTahâre" adlı üçüncü risale, el-Ḳuhistânî'nin Cami 'u'r-Rumûz Şerhu Muhtasari'l-Vikâye adlı şerhinde "Kitâbi't-Tahâre" ifadesinin i'râbına dair yaptığı açıklamalar hakkındadır.

Anahtar Kelimeler: Eyyubizade (Ejubović) el-Mostari, Şeyh Yuyo, Teftazani, Curcani, Kuhistani.

\section{Examination of Mustafa Ayyubi-zade (Ejubovic) al-Mostari's Works and Critical Edition of His Three Epistles on Arabic Language and Rhetoric}

\section{Abstract}

One of the most eminent Bosnian scholars of Ottoman era is Mustafa Ayyubi-zade (Ejubovic) al-Mostari nicknamed Sheikh Jujo (Sejh Jujo) who got higher education in İstanbul and composed more than thirty works. In this study, a detailed examination was done about the works and the manuscript copies of those works located in different libraries belonging to Ayyubi-zade, by comparing the information which was given by himself, his student 
Ibrahim Opijac al-Mostari, library catalogues, other sources and the mansucript copies of his works obtained from the libraries. Thus, deficiencies and mistakes existing in sources related with works and manuscript copies of his works were detected and corrected. Besides, in this study a critical edition of Ayyubi-zade's three small volume epistles on Arabic language and rhetoric was done. First epistle named Risala fi Bayan Ijtimai al-Istiare al-Tabaiyya maa alTamthiliyya is on the famous discussion between al-Taftazani and al-Sayyed al-Sharef alJurjani which took place in Amir Timur's palace about the occurrence of al-istiare al-tabaiyya and al-istiare at-tamthiliyya at the same time in 5th. verse of Baqarah Surah. Second epistle named Risala fi Kawn al-Jumla Mutlaqan Habaran li al-Mubtada is on another dispute between al-Taftazani and as-Sayyed al-Sharef al-Jurjani about the permissibility of insha sentence as knowledge without interpretation (ta'weel). Third epistle named Risala fi ma Qala al-Quhistani an Irab Ibarati "Kitab al-Tahara" is on syntactic analysis of al-Quhistani about the phrase of "Kitab al-Tahara" in his commentary named Jami al-Rumuz Sharh Mukhtasar al-Wiqaya.

Keywords: Ayyubi-zade (Ejubovic) al-Mostari, Sheikh Jujo, Taftazani, Jurjani, Quhistani. 


\section{GİRIŞ}

Şeyh Yuyo (Šejh Jujo) lakabı ile meşhur olmuş Mustafa b. Yusuf b. Murad Eyyûbîzâde (Ejubović) el-Mostarî (ö. 1119/1707), üç dilde ve çeşitli alanlarda telif ettiği otuzdan fazla eser ile Osmanlı döneminde en çok eser telif etmiş Bosnalı âlimdir. Eğitim almak için geldiği ve on beş yıl kaldı ̆̆ İstanbul'da Osmanlı ilim çevrelerinde tanınan bir âlim olmuştur (Bursalı, 1333/1914-15, C. 2, s. 30-32).

Eyyûbîzâde el-Mostarî'nin te'lif ettiğ eserler arasında Arap diline dair eserler de bulunmaktadır. Hayatı ve eserlerini araştırırken Arap diline dair üzerine çalışmalar yapılan Şerhu Unmûzeci'z-Zemahşerî fìn-Nahv (el-Fevâidi'l-'Abdiyye) ve Şerhu'l'-'Avâmili'l-Mie adlı eserlerinin yanında sadece Gazi Husrev Begova (GHB) Ktp. kataloğu ve birkaç kaynakta adı geçen Risâle fì Beyâni İctimâ 'i'l-İsti'âreti'l-Tebe'iyye me'a't-Temsîlliyye ve Risâle fì Kevni'l-Cumle Muțlakan Haberan li'l-Mubteda' adlı az hacimli iki risalesinin olduğu görülmüştür. Bu iki risalenin Hırvatska Akademija Znanosti i Umjetnosti (HAZU) Ktp. 1410 nr.da kayıtlı yazma içerisindeki nüshaları temin edildiğinde adı geçen iki risaleye ek olarak Eyyûbîzâde'nin yine Arap dili üzerine te'lif etttiği daha önce adı kaynaklarda bahsedilmeyen Risâle fî̀ mâ Kâle elKuhistân̂̀ 'an I'râbi 'İbareti "Kitâbi'ț-Ṭahâre" adlı tek varaklık bir risalesinin daha olduğu tarafımızdan tespit edilmiştir.

Çalışmanın ikinci bölümünde tahkikleri yapılan bu risalelerden ilki Timur huzurunda Sadeddin et-Teftâzânî (ö. 792/1390) ve es-Seyyid eş-Şerîf el-Curcânî (ö. 816/1413) arasında gerçekleşen ve âlimler arasında ihtilaf oluşmasına neden olan [Kur'ân-1 Kerim, 2: 5] (İşte onlar Rab'lerinden (gelen) bir doğru yol üzeredirler...) ayetinde على kelimesinde istiâre-i temsiliyye ve istiâre-i tebeiyyenin bir arada bulunup bulunamayacağ konusu üzerinedir. İkinci risale yine et-Teftâzânî ve el-Curcânî arasındaki bir diğer ihtilaf olan inşâ cümlesinin te'vil olmadan haber olup olamayacağı konusundadır. Üçüncü risale ise Şemseddin Muhammed el-Ḳuhistânî (ö. 962/1555)'nin Cami 'u'r-Rumûz Şerhi Muhtașari'lVikâye adlı eserinde "Kitâb eț-Ṭahâre" ifadesinin irabına dair yaptığı açıklamalar hakkındadır.

$\mathrm{Bu}$ çalışmada ele alınan risalelerin tahkikine geçmeden önce müellifin hayatı ve eserleri hakkında bilgi verilmesi amacıyla kaynaklar incelediğinde Eyyûbîzâde'nin özellikle şerh, haşiye ve ta'lik türü eserlerinin kütüphane kayıtlarında ve kaynaklarda farklı isimlerle adlandırıldığı, bazı eserlerine ve eserlerin çeşitli kütüphanelerde bulunan nüshalarına dair kaynaklarda yanlış ve eksik bilgiler bulunduğu görülmüştür.

Eyyûbîzâde, GHB Ktp. 3858/1 nr.da kayıtlı Muntecabu'l-Huș̂̂l fì Şerhi Muntehabi'l-Uș̂ul adlı eserin 1a varağına te'lif ettiği 24 eseri kaydetmiştir. Ayrıca Eyyûbîzâde eserlerinin bazılarına özel isim vermiş ve yazma nüshalarının başlarına bu isimleri not etmiştir. Öğrencisi İbrâhîm Opijač el-Mostârî (ö. 1137/1724-25), vefatının ardından Mustafa Eyyûbîzâde'nin biyografisine dair Risâle fì Menâkı̣ıi'ş-Şeyh Yûyâ Muștafâ b. Yûsuf el-Mûstârî adlı 9 varaklık Arapça bir eser kaleme almıştır. Bu risalede Eyyûbîzâde'nin 27 eserinin adını yazmıştır. Ayrıca Eyyûbîzâde ve öğrencisi Opijač'ın bahsetmediği ancak Eyyûbîzâde'ye ait olan başka eserler de vardır. Bunun yanında Mustafa Sıdkı Karabeg el-Mostarî (ö. 1878)'ye ait Ḥıdâdu'n-Nușûl adlı eserin de kaynaklarda yanlışlıkla Eyyûbîzâde'ye nispet edildiği görülmüştür.

Bu nedenle bu çalışmanın ilk bölümünde Eyyûbîzâde'nin eserleri hakkında bilgi verilirken genel bir bilgi vermekten ziyade kendisi ve öğrencisi Opijač' 1 n verdiği listeler, kütüphanelerden temin edilen nüshalar, kütüphane katalogları ile diğer kaynaklardaki 
bilgiler karşılaştırılarak eserleri ve nüshalarına dair eksiklik ve yanlışlıkların düzeltilerek bu boşluğun doldurulması hedeflenmiştir.

\section{BÖLÜM: MUSTAFA EYYÛBÎZÂDE EL-MOSTARÎ'NİN HAYATI VE ESERLERİ:}

\section{Hayatı:}

Tam adı Mustafa b. Yusuf b. Murad Eyyûbîzâde (Ejubović) el-Mostârî'dir. Bosna'da Šejh Jujo (Şeyh Yuyo) lakabı ile tanınmaktadır. Safvet-beg Bašagić, Jujo lakabı ile ilgili olarak Hersek bölgesinde Mustafa ismini kısaltması olarak Mujo denildiğini ve zamanla ses benzerliğinden bu kelimenin Jujo'ya dönüşmüş olabileceğini söylemektedir (Bašagić, 1986, s. 159). Šejh Jujo lakabı Šehjuj şeklinde de ifade edilmektedir (Udovićić, 1900-01, s. 254). Osmanlı ilim dünyasında Ejubovič soyadının karşılığı olarak Eyyûbîzâde ismi ile anılmıştır.

Eyyûbîzâde el-Mostârî, Muntecabu'l-Hușûl fì Şerḥi Munteḩabi'l-Ușûl adlı eserinin mukaddimesinde ilimde bilgisini yükseltmek ve ilim ehlinden bizzat dinleyerek ilim öğrenmek için İstanbul'a geldiğini, 15 yıl ve 1 ay gece gündüz ilimle meşgul olduğunu,

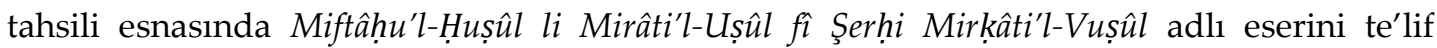
ettiğini sonra cildinin toprağına ilk değdiği diyara (Mostar) döndüğünü yazmaktadır (Eyyubizâde, yz. 3858/1, 1b-2a).

Öğrencisi olan İbrâhîm Opjiač el-Mostarî, Arapça kaleme aldığı Risâle fî Menâkibi'şŞeyh Yûyâ Muștafâ b. Yûsuf el-Mûstârî adlı biyografik eserde Eyyûbîzâde'nin hayatı hakkında bilgiler vermiştir.

Opijač’ın yazdığına göre Eyyûbîzâde, 1061/1651 yılında Mostar'da doğdu. Babası Yûsuf b. Murâd, Eyyûbîzâde gibi âlim birisiydi ve ondan ders alanlardan birisi de Opijač'ın babası Şeyh İsmail Opijač idi. Şeyh İsmail, hocasının kızı ve Eyyûbîzâde'nin kız kardeşi ile evlenmişti. Ancak bu hanım Opijač'ın öz annesi değildir. Yûsuf b. Murâd, Eyyûbîzâde 7 veya 9 yaşında iken vefat etti. Eyyûbîzâde, Mostar'da ilk eğitimini Ahmed Opijač, Şeyh İsmâîl Opijač, Müftü Hasan Efendi ve Kadı Molla İsmail'den aldı. Mostar'daki eğitimini tamamladıktan sonra ilim ehlinden bizzat eğitim almak için 1088 Receb başında (1677 Eylül) İstanbul'a gitti. İstanbul'da Molla Salih, Molla Karabekir et-Tirevî ve Arapzâde'den ders aldı. İstanbul'da çok yoğun bir şekilde ilimle uğraştı. Tahsili esnasında Molla Hüsrev'in Mirâtu'l-Uș̂̂l adlı eserine Miftâhu'Huṣ̂̂l adıyla bir şerh yanında münazara ilmine dair bir risale te'lif etti ve bu risaleyi iki kere şerh etti. Eyyûbîzâde, İstanbul'da on beş sene bir ay kalmıştır. Mostar Müftüsü Molla Hasan vefat edince Mostar ahalisinin talebi üzerine "Vatan sevgisi olmasaydı ülkeyi kötülük harap ederdi" atasözünü söyleyerek vatanına olan muhabbet sebebiyle Mostar müftülüğü görevini kabul etti. 1119 senesi Rebiulahir ayının onbeşinde (16 Temmuz 1707) vefat etti. Eyyûbîzâde, orta boylu, orta uzunlukta sakala sahip, izzetli, vakarlı, tevazu sahibi ve zekâsı çok kuvvetli birisiydi. Fetva, ders verme ve eser telif etme meşguliyetleri yanında her gün başka âlimlerin kitaplarını istinsah ederdi. Kitaplardaki hataları tashihe ve kitapların kenarlarına faydalı notlar yazmaya çok önem verirdi. Arkasında telif ettiği eserler ile kitapların kenarlarına ve boş yerlerine yazdıkları haricinde istinsah etmiş olduğu 60 ciltten fazla eser bıraktı. Eyyûbîzâde evliydi ancak hiç çocuğu olmadı (Opijač, yz. 3858, 2b-8b).

Bursalı Mehmed Tahir, İbrâhîm Opijač'in Mustafa Eyyûbîzâde'nin kayınbiraderi olduğunu söylemektedir (Bursalı, 1333/1914-15, C. 2, s. 30). Ancak bu husus doğru değildir. Mustafa Eyyûbîzâde, Opijač' in babasının kayınbiraderidir. 
Eyyûbîzâde adına Hersek Eyaleti Beylerbeyi Ali-paša Rizvanbegović tarafından 1247/1831'de Mostar'daki Šarića Cami karşındaki mezarlıkta türbe yaptırılmıştır. Eyyûbîzâde'nin kabrine gelenlerin ilimde karşılaştıkları zorlukların üstesinden gelmesi ile ilgili duasından mütevellit halk arasında başarısız çocukların her sabah namazından sonra 40 gün boyunca mezarında Yasin okuması sonucu akıllı olacaklarına dair bir inanış vardır. Ayrıca türbesi çeşitli isteklerinin gerçekleşmesini umanlar tarafından ziyaret edilen bir yer konumundadır (Bašagić, 1986, s. 162; Hasandedić, 2005, s. 111; A. Nametak, 1992, s. 16).

\section{Eserleri:}

Eyyûbîzâde'nin Kaydettiği Eserler: Eyyûbîzâde'nin eserlerine dair müracaat edilecek ilk kaynak kendisinin kaleme aldığı eserlerine dair kayıttır. Müellif hattı nüshası GHB Ktp. 3858/1 nr.da kayıtlı Muntecabu'l-Hușûl fî Şerḥi Munteḩabi'l-Ușûl adlı eserin 1a varağında Eyyûbîzâde tarafından kaydedilen ve GHB Ktp. 4027 nr.da kayıtlı Fetḥu'l-Esrâr adlı eserinin baş tarafına öğrencisi İbrahim Opijač tarafından müellif hattından nakledilen bu notta te'lif sırasına göre listelenmiş 24 eser yer almaktadır. Müellif, bu notta eserlerinin isimlerini verirken şerh, ta'lik, haşiye, tahrir ve imlâ gibi eserin türüne işaret eden ifadeler kullanmıştır.

Bu notta yer alan eserler, müellifin ifadesine uygun bir şekilde sırasıyla şunlardır:

1.Şerḥu Risâleti'l-Âdâb: Bazı kaynaklarda Ebû'l-Ḳâsım el-Leys es-Semerkandî (ö. 888/1483)'nin Ferâ'idu'l-Fevâ'id adlı eserine yazılmış bir şerh olduğu yazmakta ise de Eyyûbîzâde'nin şerh yazdığı eser Şemseddîn Muhammed b. Eşref es-Semerkandî (ö. 702/1303)'nin âdâb üzerine yazdığı risaledir. Ayrıca el-Leys es-Semerkandî'nin yazdığı risale adab üzerine değil belagata dair isti‘are konusu üzerinedir. Bir nüshası Bratislava Ünivesitesi Ktp. TF 119 nr. da Şerhu Risâle fì Âdâbi'l-Bahs adıyla kayıtlıdır (Univerzitna Knižnica v Bratislave [UKB], 2020).

2.Şerḥu Ḥaavâşî Şerḥi Risâleti'l-Âdâb: Şemseddîn es-Semerkandî'nin adaba dair risalesine Mesud er-Rûmî'nin yazdığ 1 şerh üzerine Ebû'l-Feth Muhammed b. Ebû Sa 'id'in yazdığı haşiyeye yazılmış bir şerhtir. Müellif hattı GHB Ktp. 3974/2 nr.da kayıtlı olup eser tamamlanmamıştır. GHB kataloğunda da müellifin eserini şerh olarak isimlendirdiği yazmaktadır (Fajić, 1999, C. 5, s. 133).

3.Ta'lị̂ 'alâ Ḥavâşî Şeyhulislâm el-Herevî: et-Teftâzânî'nin Telhiṣu'l-Miftâh üzerine yazdığı şerh olan Muhtașaru'l-Me ân̂̂ adlı esere torunu Şeyhulislam el-Herevî Ḥafid etTeftâzânî'nin yazdığı haşiye üzerine yazılmış bir haşiyedir. Amir Ljubović, eserin Mostar Fransisken Manastırı Ktp. R-60 nr.da kayıtlı bir nüshası olduğunu ifade etmektedir (Ljubović, 1995, C. 12, s. 34). Ancak bu nüsha Eyyûbîzâde'ye ait Hâş̧iyetu'l-Muhtașar li Mevlâna Suleymân b. 'Abdurrahman el-Mağribî es-Semûnî adlı eserin nüshasıdır (Hasandedić, 1982, s. 163).

4.Şerḥu Risâleti'1-Manțḳ̣ (Şerḥu Îsâgûucî): Eyyûbîzâde'nin mantığa dair bu risaleye yazdığı şerhi, tek basılmış eseridir. Eyyûbîzâde, eserini, 23 Şaban 1093 (27 Ağustos 1682)'de tamamlamış olup Abdurrahman Paşa'ya ithaf etmiştir. 1316/1898-99 tarihinde Tajib Okić (Tayyip Okiç)'in babası Mehmed Teufik Okić tarafından İstanbul'da basılmıştır (Bašagić, 1986, s. 165). Müellif hattı GHB Ktp. 3974/1 nr.da kayıtlıdır. Ayrıca GHB Ktp. 3578, 3675, 2017; HAZU Ktp. 1408/1, 1407/3, 1206/2; Bratislava Ünivesitesi Ktp. TE 15 (UKB, 2020); Süleymaniye Ktp. Kılıç Ali Paşa 661 nr.da kayıtlı yazma nüshaları ile Süleymaniye Ktp. Celal 
Ökten 347, İd Mehmed Efendi 68, Tirnovalı 1311 nr.da kayıtlı 78 sayfalık Matbaa-i Amire'de 1316/1898-99' de basılmış basma nüshaları vardır.

5.Ta'lị̂u Ḥavâşî Şerḥi Risâleti'l-Manțı̣ li'l-Fenârî: Molla Fenârî (ö. 834/1431)'nin elFevâ'idu'l-Fenâriyye fì Şerhi'r-Risâleti'l-Eŝîriyye adlı şerhi üzerine yazılmış bir haşiyedir. 1 Ramazan 1093 (17 Mayıs 1692)'de tamamlanmıştır. Müellif hattı HAZU Ktp. 198 nr.da kayıtlıdır (Ždralović, 1981, s. 128). Eserin bir nüshası GHB Ktp. 3736/2 nr.da kayıtlıdır.

6.Risâle fí'l-Âdâb (Hulâșatu'l-Âdâb): Âdâb ilmi üzerine bir risaledir. GHB Ktp. 1766/6, 2864/4; HAZU Ktp. 1525/3 ve Stolac'da Habibe Mehmedbašić şahsi koleksiyonu MH/3 nr.da kayıtlı nüshaları vardır (Ždralović, 1981, s. 130; Ćeman, 2011, s. 23). Bir nüshası da Bratislava Üniversitesi Ktp. TC 8 nr.da kayıtlıdır. Bu nüshada aynı zamanda el-Hasan b. Ahmed el-Bosnasarayî Sipahizade tarafından bu esere yazılmış ancak tamamlanmamış bir şerh vardır (Petraček \& Blaškovič, 1960, s. 13; UKB, 2020).

7.Şerḥu Muhtașar fî Hulâșati'l-Âdâb: Âdâb ilmi üzerine yazdığı risalenin kısa şerhidir. Nüshası tespit edilememiştir.

8.Şerḥu Muțavvel fî Hulâșati'l-Âdâb: Âdâb ilmi üzerine yazdığı risalenin uzun şerhidir. Nüshası tespit edilememiştir. Amir Ljubović, GHB Ktp. 3855 nr.da kayıtlı bir nüshası olduğunu yazmaktadır (Ljubović, 1995, C. 12, s. 34). Ancak bu nüsha Eyyûbîzâde'nin es-Semerkandî'nin risalesine Mesud eş-Şirvânî'nin yazdığı şerh üzerine Ebû'l-Feth Muhammed b. Ebû Sa 'id'in yazdığı haşiye üzerine yazılmış bir haşiyedir.

9.Şerḩu Unmûzeci'z-Zemahsşerî fî'n-Naḥv (el-Fevâidi'1-‘Abdiyye): ez-Zemahşerî (ö. 538/1144)'nin Unmužec fi'n-Naḩ adlı eserine yazılmış bir şerhtir. Öğrencisi Abdurrahman Paşa'nın oğlu Abdullah Bey'in isteği üzerine te'lif ettiği için Molla Câmî'nin el-Fevấidu'ḍDıyaiyye adlı eserine benzer bir isim vermiştir. 18 Receb 1094 (13 Temmuz 1683) tarihinde tamamlanmıştır. Eserin müellif hattı nüshası GHB Ktp. 3883 nr.da kayıtlıdır. Diğer nüshaları GHB Ktp. 4871/1, HAZU Ktp. 1563, Arhiv Hercegovina (AH) Ktp. 298 nr.da kayitlidır. Kaynaklarda eserin Belgrad Üniversitesi Ktp. ve Mostar Fransisken Kilisesi Ktp.nde kayıtlı nüshaları olduğu yazmasına rağmen ilgili kütüphanelerin kataloglarında eserin nüshasına rastlayamadık. Eserin Orijentalni Institut u Sarajevu (OIS) Ktp. 57/50 nr.da kayıtlı bir nüshasının olduğu kaynaklarda yazmasına rağmen 1992 yılındaki savaşta kütüphaneye yapılan saldırıda bu nüsha yok olmuştur. Ayrıca kaynaklarda eserin Merkezu Melik Faysal Ktp. 2583, Merkezu'1-Bahsi'l-'İlmiyye Ktp. 1029, el-Câmi'atu'l-İslâmiyye Ktp. 6543/1 ve elEsed Ktp. 14285 nr.da kayıtlı nüshaları olduğu yazmaktadır (Merkezu Melik Faysal [MKF], 2020, nr. 55704, 64431; Câmi 'u'l-Mahtutâti'l-İslamiyye [CMİ], 2020).

Eser üzerine Mustafa Jahić, 1994 yılında Saraybosna Üniversitesi'nde Gramatička Obrada Akuzativa u Djelu "al-Fawa'id al-Abdiyya" Mustafe Ejubovića-Šejh Juje (Mustafa Ejubović-Šeyh Jujo'nun "el-Fevâi'du'l-'Abdiyye" Eserinde İsmin -i Halinin Gramer Açısından İşlenmesi) adıyla yüksek lisans çalışması yapmıştır. Ayrca Fâleh Bedâh Abdullah el-'Acemî, 2015 yılında Ürdün'deki eş-Şarku'l-Evsat Üniversitesi'nde eserin tahkikini içeren bir yüksek lisans çalışması yapmıştır.

10.Ta'lị̂u Ḥavâşî 'alâ Ḥavâşî'l-Âdâbi'l-Miriyye: 'Adududdin el-Î̂î (ö. 756/1355)'nin âdâba dair te'lif ettiği esere Muhammed el-Hanefî et-Tebrîzî (ö. 900/1494)'nin yazdığı şerh üzerine Muhammed b. Mir el-Erdebilî (ö. 950/1534)'nin yazmış olduğu haşiye üzerine yazılmış bir haşiyedir. 25 Rebiulahir 1095 (11 Nisan 1684)'de tamamlanmıştır. Müellif hattı 
nüshası GHB Ktp. 3987 nr.da kayıtlı olup GHB Ktp. 5802/2 nr.da kayıtlı bir nüshası daha vardır (Fajić, 1999, C. 5, s. 262, 267).

11.Ta'lị̂ 'alâ Ḥavâşî Şerḥi'l-Âdâbi'l-Mes'ûdî: Şemseddîn es-Semerkandî'nin risalesine Mesud er-Rûmı̂'nin yazdığ 1 şerh üzerine Ebû'l-Feth Muhammed b. Ebû Sa 'id'in yazdığı haşiye üzerine yazılmış bir ta'likdir. Müellif hattı nüshası GHB Ktp. 3855 nr.da kayıtlıdır (Fajić, 1999, C. 5, s. 237).

12.Ta'lîḳ̣ 'alâ Şerhii'l-Âdâbi'l-Mes'ûdî: Şemseddîn es-Semerkandî'nin risalesine Mesud er-Rûmî'nin yazdığı şerh üzerine yazılmış bir haşiyedir. es-Semerḳandî ve erRûmî'nin âdâba dair ifadelerinin şerhine ait Bratislava Üniversitesi Ktp. TF 32 nr.da kayıtlı bir yazmanın Eyyûbîzâde'ye ait olduğu tahmin edilmektedir (Petraček-Blaškovič, 1960, s. 13).

13.Şerḥu'l-Ḳaṣîdeti'1-Lâmiyye (Bedru'1-Me‘âlî fî Şerḥi Bed'i'l-Emâlî): Sirâcuddin Ali el-Fergânî el-Ûşî (ö. 569/1173)'nin akaide dair el-Kașîdetu'l-Lâmiyye adlı eserinin şerhidir. Bir nüshası OIS Ktp. 3524/1 (57/50) nr.da kayıtlı iken 1992 yılındaki savaşta kütüphanedeki birçok eserle beraber yok olmuştur.

14.Ta'lị̂ụu Ḥavâşî 'alâ Şerhịi'l-Ḳașîndeti'l-Lâmiyye li'l-Ḳarâbâgîi: el-Ûşî'nin elKaṣîdetu'l-Lâmiyye adlı eserine Muhyiddin el-Ḳarâbâgîi (ö. 942/1535)'nin yazdığı şerh üzerine yazılmış bir haşiyedir. Müellif hattı nüshası AH Ktp. 212 nr.da kayıtlıdır. GHB Ktp. 301/6 nr.da kayıtlı bir nüshası daha vardır (Fajić, 1991, C. 3, s. 300). Diğer bir nüshası OIS Ktp. 3524/2 (237) nr.da kayıtlı iken 1992 yılındaki savaşta yok olmuştur. Hazim Šabanović, Carl Brockelmann'ın eserini kaynak göstererek eserin St. Petersburg (Leningrad)'da bir nüshasının olduğunu yazmıştır. Ancak kütüphane kataloğunda Eyyûbîzâde'ye ait herhangi bir esere rastlamadık. Diğer taraftan Brockelmann, el-Uşî'nin eseri ve şerhlerinin St. Petersburg ile diğer kütüphanelerde bulunan nüshalarını yazarken Eyyûbîzâde'nin şerhinden bahsetmemektedir (Brockelmann, 1937, C. Sup. I, s. 764-65; Šabanović, 1973, s. 408; Institute of Oriental Manuscripts in Saint Petersburg [IOM], 2020).

15.eş-Şerḥu'1-Cedîd (Şerḥu Şemsiyyeti'1-Manțı) ): Necmeddin Ali b. Ömer el-Kâtibî (ö. 675/1277)'nin mantık ilmine dair er-Risâletu'ş-Şemsiyye adlı eserinin şerhidir. 17 Cemaziyelahir 1101 (28 Mart 1690)'de tamamlanmıştır. Müellif hattı nüshası Kahire Dâru'1Kutub Ktp. 183 nr.da kayıtlıdır. GHB Ktp. 793 ve HAZU Ktp. 1407/2 nr.da kayıtlı nüshaları vardır (Ždralović, 1981, s. 121, 126; Šabanović, 1973, s. 403). Opijač, bu eserin nadir kitaplardan verdiği faydalı bilgilerin eşsiz olduğunu söylemiştir (Opijač, yz. 3858, 8a). Kaynaklarda Princeton Ktp. 1403 nr.da kayıtlı bir nüshası daha olduğu yazmaktadır (MKF, 2020, nr. 111133). Ayrıca Dâru'l-Kutub Ktp. 365/2 nr.da Eyyûbîzâde'ye ait Şerḥu'l-Mizâni'lManțı adlı bir eser kayıtlıdır (MKF, 2020, nr. 35750).

16.Ta'lîku Ḥavâşî 'alâ Şerḥi Risâleti'l-Vaḍ': 'Adududdin el-Îcî (ö. 756/1355)'nin vaḍ' (lafız-anlam ilişkisi) ilmine dair yazdığı risaleye 'Isâmuddîn el-İsferâyînî (ö. 945/1538)'nin yazdığ1 şerh üzerine yazılmış haşiyedir. 1102/1691 yılında tamamlanmıştır. Müellif hattı nüshası GHB Ktp. 3957 nr.da kayıtlıdır.

17.Ta'lîḳu Ḥavâşî 'alâ Risâleti'l-Ḥanefiyye fî̀l-Âdâb: 'Adududdin el-Îcî'nin âdâba dair eseri üzerine Muhammed el-Hanefî'nin yazdığ şerh üzerine yazılmış bir haşiyedir. Müellif hattı nüshası GHB Ktp. 3915 nr.da kayıtlıdır. 21 Cemaziyelevvel 1102/20 Şubat 1691'de tamamlanmıştır (Fajić, 1999, C. 5, s. 259).

SEFAD, 2020; (44): 131-160 
18.Şerḥu Mirâti'l-Ușûl fî Şerḥi Mirḳâti'l-Vuṣûl (Miftâhư'l-Ḥuṣûl): Molla Hüsrev'in Mirkâtu'l-Vuṣûl adlı fıkha dair eserine yine Molla Hüsrev tarafından yazılan Mirâtu'l-Uș̂ul adlı şerh üzerine bir haşiyedir. Eyyûbîzâde, bu eseri tahsili esnasında kaleme aldığını ifade etmiştir. 1103/1691 yılında tamamlanmıştır. Bursalı Mehmed Tahir, bu şerhin Osmanlı ilim sahasında çok itibar gördüğünü söylemektedir (Bursall, 1333/1914-15, C. 2, s. 30; K. Çelebî, 1941, C. 2, s. 1657; el-Murâdî, 1301/1883-84, C. 6, s. 219). Müellif hattı nüshası GHB Ktp. 3871 nr.da kayıtlıdır. HAZU Ktp. 1404 ve 1527 nr.da kayıtlı nüshaları vardır (Šabanović, 1960, s. 31; Ždralović, 1981, s. 124). Diğer nüshaları Süleymaniye Ktp. Süleymaniye 561, Hamidiye 440; Atıf Efendi Ktp. 690; Nurosmaniye Ktp. 1322 ve 1323; Ragıp Paşa Ktp. 003 ve 393; Damadzade Murat Molla Ktp. 716 nr.da kayıtlıdır. Elektronik kaynaklarda eserin ezZahiriyye Ktp. 2808 nr.da kayıtlı bir nüshasının daha olduğu yazmaktadır (CMİ, 2020).

Eserin tahkikine dair Abdulaziz b. Abdurrahman el-Belihid tarafından 2016 yılında Medine'de el-Cami 'atu'l-İslâmiyye Üniversitesi'nde doktora çalışması yapılmıştır.

19.Şerḥu'l-Mug̉nî fi'l-Ușûl (Fetḥu'1-Esrâr): Celaleddin Ömer el-Hुucendî (ö. 691/1292) tarafından fıkıh alanında te'lif edilen Kitâbu'l-Muginn̂ fì Uș̂̂l adlı eser üzerine yazılan bir şerhtir. 29 Safer 1109 (16 Eylül 1697) tarihinde tamamlanmıştır. Müellif hattı nüshası GHB Ktp. 4027 nr.da kayıtlıdır. Süleymaniye Ktp. Halet Efendi 146 nr.da kayıtlı bir nüshası daha bulunmaktadır.

20.Şerḥu'1-Muntehab fî́l-Ușûl (Muntecabu'l-Ḥuṣûl): Muhammed el-Husamî elAhsîkatî (ö. 644/1247)'ye ait fıkıh alanında te'lif edilen Muntahab fî Ușûli'l-Mežheb adlı eserin şerhidir. Eyyûbîzâde, bu eseri yazmaya Rebiulevvel 1109 (Eylül 1697) tarihinde başlamış ve 13 Cemaziyelevvel 1110 (17 Kasım 1698) tarihinde tamamlamıştır. Müellif hattı nüshası GHB Ktp. 3858 nr.da kayıtlı olup bu nüshanın 1a varağında Eyyûbîzâde tarafından yazılan 24 eserinin yer aldığı liste ile hocası Arapzade'nin şeceresine dair kayıt vardır. Diğer bir nüshası AH Ktp. 349 nr.da kayıtlıdır. Amir Ljubović, eserin Süleymaniye Ktp. Celal Ökten 131 nr.da kayıtlı bir nüshası daha olduğunu ifade etmektedir (Ljubović, 1995: C. 12, s. 34). Ancak bu yazma kütüphane kayıtlarında Eyyûbîzâde'ye nispet edilmesine rağmen Mustafa Sttki Karabeg el-Mostarî (ö. 1295/1878)'ye ait olan Hidâdu'n-Nuș̂̂l (Haşiye 'alâ Mirâti'l-Ușûl fî Şerhi Mirkâti'l-Vușûl) adlı eserin basma nüshasıdır (el-Mostarî, t.y., 1; Handžić, 1992, s. 188).

21.Şerḥu Risâleti'l-Ferâ'iḍ: Ebû'l-Berekât en-Nesefî (ö. 710/1310)'nin fera'iḍ (İslam miras hukuku) ilmine dair risalesine yazılmış bir şerhtir. Müellif hattı nüshası GHB Ktp. 3860/2 nr.da kayıtlıdır (Dobrača, 2002, C. 2, s. 892-93; Šabanović, 1960, s. 34). GHB Ktp. 3860 nr.da kayıtlı yazmanın baş tarafında yazmadaki dört eserin isimleri yazılmıştır. Eser bu listede Şerḥu Risâleti Șâhibi'l-Medârik İmâmi'n-Nesefì şeklinde yazılmıştır (Eyyûbîzâde, yz. 3860, 0b). Kaynaklarda eserin Riyad Merkezu Melik Faysal Ktp. 2268 nr.da kayıtlı bir nüshası daha olduğu yazmaktadır (MKF, 2020, nr. 111949).

22.Lubbu'1-Ferâ'iḍ: Feraiḍ ilmine dair bir eserdir. Amir Ljubović, GHB Ktp. 3860/1 nr.da Lubbu'l-Ferấid ve GHB Ktp. 3860/2 nr.da Şerḥu Lubbi'l-Ferâ'iḍ adlı eserlerin kayıtlı olduğunu belirtmektedir (Ljubović, 1995, C. 12, s.34). Hazim Šabanaovič ise GHB Ktp. 3860 nr.da Lubbu'l-Ferâ'iḍ ve 3860/1 nr.da Şerhu Lubbi'l-Ferâ'id' in adlı eserlerin kayıtlı olduğunu yazmaktadır (Šabanović, 1960, s. 34; Šabanović, 1973, s. 408). Ancak GHB Ktp. 3860 nr.da kayıtlı yazmanın ilk eserinin başında kırmızı mürekkep ile Şerḥu Lubbi'l-Ferâ'id yazmaktadır. 1a varağının yan tarafına yazma mecmuada yer alan 4 eserin isimleri yazılmış olup birinci 
eser Şerḥu Lubbi'l-Ferấ'ị'dir (Eyyûbîzâde, yz. 3860, 1a). GHB kataloğunda da yazmadaki ilk eser Şerḥu Lubbi'l-Ferâ'iḍ olarak geçmektedir (Dobrača, 2002, C. 2, s. 892-93).

23.Şerḥu Lubbi'l-Ferâ'iḍ: Eyyûbîzâde'nin feraiḍ ilmine dair kendi risalesine yazdiğ1 şerhtir. Opijač, hocasının bu şerhi 9 günde tamamladığını yazmaktadır (Opijač, yz. 3858, 8a). Müellif hattı nüshası GHB Ktp. 3860/1 nr.da kayıtlıdır (Dobrača, 2002, C. 2, s. 892-93). GHB Ktp. 3860 nr.da kayıtlı yazmanın baş tarafında yazmadaki dört eserin isimleri yazılmıştır. Eser, bu listede Şerḥu Lubbi'l-Ferâ'id ilâ'l-Munâsahâat şeklinde yazılmıştır. Nüsha, eserin elMunâsahât konusuna kadar olan kısmını içermektedir (Eyyûbîzâde, yz. 3860, 0b). Bir nüshası HAZU Ktp. 1565 nr.da kayıtlıdır (Ždralović, 1981, s. 129). Kaynaklarda eserin Riyad Merkezu Melik Faysal Ktp. 2268 nr.da kayıtlı bir nüshası olduğu yazmaktadır (MKF, 2020, nr. 111948).

24.Şerḥu Tehẓîbi'l-Manțı̣̣ ve'l-Kelâm (Tavḍị̂u Tehżîbi'l-Manțı̣̣ ve'1-Kelâm): etTeftâzânî'nin mantı̆̆a dair Tehzî̉i'l-Manțk ve'l-Kelâm adlı eserinin şerhidir. Eyyûbîzâde'nin telif ettiği son eserdir. Opijač, hocasının 4 Receb 1118 (13 Eylül 1706)'da eseri tamamladığını, okumak için izin aldığını, istinsah etmeye başladığını ve 30 varağını yazdığı esnada hocasının 16 Rebiulahir 1119 (17 Temmuz 1707)'de vefat ettiğini söylemiş̧tir (Opijač, yz. 3858, 8a). Müellif hattı OIS Ktp. 23 nr.da (eski nr. 1668) kayıtlıdır. 1992 yılındaki savaşta kütüphanedeki 5200 civarında yazma yok olmuş, geriye kalan 53 yazmanın bir tanesi de Eyyûbîzâde'nin müellif hattı nüshasıdır (Gazić, 2009, s. 63). Yazmanın başında Eyyûbîzâde'ye ait temellük kaydı ve mühür ile sonunda Opijač tarafından eserin müellif hattı olduğuna dair not, eserin vakıf kaydı ile Eyyûbîzâde'nin vefat tarihine dair Opijač'ın tarih düşürme sanatı ile verdiği iki şatıra dair notlar yer almaktadır (Eyyûbîzâde, yz. 23, 0a). Bir nüshası HAZU Ktp. 412 nr.da kayıtlıdır (Ždralović, 1981, s. 128).

İbrahim Opijačı'ın Kaydettiği Eserler: Opijač, Risâle fì Menâkibi'ş-Şeyh̆ Yûyâ adlı eserinde hocasına ait 27 eser saymıştır. Bu eserler arasında yukarıda verilen Eyyûbîzâde'nin kaydettiği eserlerde yer alıp da Opijač’ın saymadığı tek eser Ta 'lị̂u Havâş̧î Şerḥi Risâleti'lManțı li'l-Fenârî́dir. Bunun yanında Opijač, risalesinde hocasının vermediği şu 4 eseri zikretmektedir (Opijač, yz. 3858, 7b-8b).

25.Şerḥ 'alâ'l-Lugati'1-Mevsûme bi'ş-Şâhidiyye (Ḥulla-i Manzûma): İbrahim Şâhidî Dede (ö. 957/1550)'nin yazdığı Farsça-Türkçe manzum sözlük olan Tuhfee-i Şâhidî adlı sözlüğün şerhidir. Eyyûbîzâde'nin tek Türkçe eseridir. Rebiulevvel 1110 (Ağustos 1698)'da tamamlanmıştır. Eserin müellif hattı nüshası OIS Ktp. 4366 (60) nr.da kayıtlı idi ancak 1992 yılındaki savaştaki saldırılar sonucu yok olmuştur. Diğer nüshaları Historijski Arhiv Sarajevo (HAS) Ktp. 222; GHB Ktp. 635, 1301, 2573, 6121, 2161 ve 8311 nr.da HAZU Ktp. 1443, 1992 nr.da kayıtlıdır. GHB Ktp. 8311 nr.da kayıtlı nüsha eserin sadece ilk 5 varaklık bölümünü ihtiva etmektedir (Ždralović, 1981, s. 121; Popara-Fajić, 2000, C, 7, s. 454-56; Popara, 2008, C. 16, s. 316-17; Popara: 2010, s. 313; Ćeman, 2011, s. 22).

26.Şerḥu Risâle fî Âdâb li's-Seyyidi'ş-Şerîfi'l-Curcânî (Zubdetu'l-Âdâb): Opijač, bu eserle ilgili es-Seyyid eş-Şerîf'e âdâb ilmi üzerine bir şey yazdın mı? diye sorulduğunu, âdâb üzerine 10 satırlık bir yazı yazdım, diye cevap verdiğini, Eyyûbîzâde'nin bu eser üzerine olan şerhinin ise 4 varak olduğu şeklinde bir açıklama yapmıştır (Opijač, yz. 3858, 8a). Bir nüshası GHB Ktp. 4871/2 nr.da kayıtlı yazmanın 105b-108a varakları arasındadır. el-Hac Muhammed b. el-Ḥac Hasan Efendi Kûtlûvî el-Mostârî tarafından istinsah edilmiştir. Mustafa Jahić, GHB kataloğunda ve makalesinde bu eserin Necmeddin el-Kâtibî'nin er-

SEFAD, 2020; (44): 131-160 
Risâletu'ş-Şemsiyye adlı eseri üzerine yazılmış haşiye üzerine te'lif edilmiş bir eser olduğunu ifade etmektedir (Jahić, 1999, C. 6, s. 64; Jahić, 1985, s. 48). Ancak er-Risâletu'ş-Şemsiyye mantık ilmi üzerinedir. Eyyûbîzâde'nin şerhi ise âdâb üzerinedir. Eyyûbîzâde, eserin mukaddimesinde el-Curcâni'nin sözünü açıklarken hamişe "fî Ḥâşiye 'alâ Şerhịi'r-Risâleti'şŞemsiyye" notunu düşerek alıntı yaptığı kaynağın adını vermiştir. Bu not eserin adı olarak kabul edilmiş olmalıdır. Ancak eser, Opijač'ın bahsettiği gibi 4 varak olup Eyyûbîzâde, eserin hamişine Opijač' 1 da bahsettiği "es-Seyyid'e âdâb üzerine bir şey yazdın mı diye soruldu, Âdâb üzerine bu sözü derledim dedi. İşte bu, onu şerhimizdir." notunu düşmüştür (Eyyûbîzâde, yz. 4871/2, 105b).

27.Şerḥu Dîbâceti'1-Muhtașari'1-Me‘ânî: et-Teftâzânî'nin Telḩișu'l-Miftâh üzerine yazığı şerh olan Muhtașaru'l-Me 'ân̂े adlı eserin dibacesine yazdığı şerhtir. Müellif hattı nüshası GHB Ktp. 4099 nr.da kayıtlıdır. AH Ktp. 634 nr.da kayıtlı bir nüshası daha vardır (Hasandedic, 1974, s. 61). Amir Ljubović, HAZU Ktp. 446 nr.da kayıtlı bir nüshasının daha olduğunu ifade etmektedir. Ancak Muhamed Ždralović, Eyyûbîzâde'nin HAZU Ktp.de bulunan eserleriyle ilgili çalışmasında bu eserin nüshasından bahsetmemektedir (Ljubović, 1995, C. 12, s. 34).

28.Nefâisi'1-Mecâlis fî̀'l-Mev'iza: Eyyûbîzâde'nin vaazlarının toplandığı bir eserdir. GHB Ktp. 3650 nr.da kayıtlı yazmanın 1-2a varaklarında Eyyûbîzâde'nin vaaza dair bir eseri vardır. Nüshanın başında mev'izanın Yuyu el-Mostârî diye meşhur Mustafa Efendi'nin te'lifi olduğu ve yaklaşık 1190/1776'de istinsah edildiğine dair bir kayıt bulunmaktadır (Fajić, 1991, C. 3, s. 3).

Diğer Eserleri: Eyyûbîzâde ve Opijač'ın bahsettiği eserlerden başka Eyyûbîzâde'nin şu eserleri vardır:

29.Şerḥu'l-'Avâmili'1-Mie: Abdulkâhîr el-Curcânî (ö. 471/1078-79)'nin irâb üzerine telif ettiği el-'Avâmilu'l-Mie, el-'Avâmilu'l-Curcânî veya el-'Avâmilu'l-Âtîk olarak bilinen eserine yapılan bir şerhtir. Eserin Süleymaniye Ktp. Bağdatlı Vehbi Efendi 1906, Kasîdecizâde Süleyman Sırrı 700/5; GHB Ktp. R-1795/6, R-5364/3; HAZU Ktp. 1566/2, 1984/3 ve Bošnjački Institut (BI) Ktp. 264/1 nr.da ve Atifa Sabrihafizović'in özel koleksiyonunda kayıtlı nüshaları bulunmaktadır. Kaynaklarda OIS Ktp. 57/50 nr.da kayıtlı nüshası olduğu yazmakta ise de 1992 yılındaki savaşta tahrip edilen kütüphanedeki diğer eserler ile birlikte yok olmuştur (Jahić, 1999, C. 6, s. 257; Ždralović, 1981, s. 131; Ždralović, 2002, s. 41; Nametak-Trako, 1997, C. 1, s. 214; Ćeman, 2011, s. 21).

Bu eser, Eyyûbîzâde ve Opijačın yazdığı kayıtlarda yer almamaktadır. Bu nedenle eserin Eyyûbîzâde'ye ait olmadığı düşünüldüğünden bazı kaynaklarda geçmemektedir. Ayrıca eserde müellifin adı diğer eserlerinin aksine el-Mostarî nisbesi olmadan sadece Mustafa b. Yusuf b. Murad olarak geçmektedir.

Eserin 1997 yılında yapılan BI Ktp. katalog çalışmasında daha önce bilinmeyen bir nüshası daha ortaya çıkarılmıştır. Katalogda BI Ktp. 264/1 nr.da kayıtlı bu nüshanın sonunda müellifin şöhreti olmamasından dolayı eserin küçümsenmemesini istediği ve eseri 15 günde tamamladığına dair notun yer aldığı yazmaktadır (Nametak \& Trako, 1997, C. 1, s. 214).

Eser üzerine Amra Mulović, Saraybosna Üniversitesi'nde Regens u Sintaksi Arapskog Jezika u Djelu Mustafe Ejubovića-Šejh Juje (Mustafa Ejubović-Šeyh Jujo'nun Eserinde Yer Alan Arap Dili Sentaksındaki Âmiller) adlı 2007 tarihli yüksek lisans çalışması yapmıştır. 
Ayrıca Rasim Fırat Yalçın, İstanbul Üniversitesi'nde Mostarlı Mustafa Efendi ve Şerḥu'l-Avâmili'l-Cürcani Adlı Eseri (Metin-Tahkik) adlı 2013 tarihli yüksek lisans çalışması yapmıştır. Bu çalışmada eserin sadece Süleymaniye Kütüphanesinde bulunan iki nüshasından faydalanmıştır.

30.Ḥ̂ş̧iyetu'l-Muhtașar li Mevlâna Suleymân b. 'Abdirraḥman el-Magiribî esSemûnî: Hivzija Hasandedić, Mostar Fransisken Manastırı Ktp. Şarkiyat Koleksiyonu üzerine yaptığı bir çalışmada Eyyûbîzâde'nin ve Opijač'ın listesinde geçmeyen ancak Mostar Fransisken Manastırı Ktp. R-60 nr.da kayıtlı Eyyûbîzâde'nin müellif hattı nüshası olan bu eserini tespit etmiştir. Eser, Eyyûbîzâde'nin de şerh ettiği Esîruddin Mufaḍdall el-Ebherî'nin Îsâgûcî olarak da adlandırılan Risâletu'l-Esîriyye adlı eserine 'Alumuddin lakaplı Suleymân b. 'Abdurraḥman el-Mağribî es-Semûnî'nin yazdığı muhtasar şerhi üzerine bir haşiyedir. Yazmanın 2a varağında Eyyûbîzâde'ye ait temellük kaydı ile 180a varağında eserin Perşembe akşamı, 4 Rebiulevvel 1099 (8 Ocak 1688)'de tamamlandığı ve te'lif edenin Mostar'dan Mustafa b. Yusuf, b. Murad olduğuna dair bir kayıt bulunmaktadır (Hasandedić, 1982, s. 163).

31.Ta'lị̂ 'alâ Ḥâşiyeti'1-Kürdî ala Ḥâşiye Şerḥi'l-Âdâb: es-Semerkandî'nin risalesine Kemaleddin Mesud er-Rûmî (ö. 905/1488)'nin yazdığ şerh üzerine Ebû'l-Feth Muhammed b. Ebî Sa'id'in yazdığı haşiyeye Abdurrahman el-Kurdî el-Amedî'nin yazdığı haşiye üzerine yazılmış bir ta'likdir. Eser kaynaklarda geçmemekte olup ilk defa GHB katalog çalışması ile tespit edilmiştir. GHB Ktp. 4617/1 nr.da kayıtlı nüshası müellif hattıdır (Fajić, 1999, C. 5, s. 235).

Bir-İki Varaklık Risaleleri: Eyyûbîzâde'nin bu eserler haricinde bir veya iki varaklık risaleleri de vardır. Eyyûbîzâde'nin çalışmanın devamında tahkiki ve incelemesi yapılan Arap dili ve belagatına dair telif ettiği az hacimli 3 risalesi vardır. Bu risaleler şunlardır:

1. Risâle fì Beyâni İctimâ 'i'l-İsti'âreti'l-Tebe'iyye me'a't-Temsîliyye:

2. Risâle fi Kevni'l-Cumle Muțlakan Haberan li'l-Mubteda':

3. Risâle fì mâ Kâle el-Kuhistânî 'an I' râbi 'İbâreti "Kitâbi'ț-Ṭahâre":

Ayrıca AH Ktp. 547 nr.da kayıtlı yazmanın 201b ile 202a varakları arasında ve HAZU Ktp. 654 nr.da kayıtlı yazmanın 11b ve 12a varakları arasında Eyyûbîzâde'ye ait helal ve haram kavramlarının açıklanmasına dair bir risale vardır (Hasandedic, 1974, s. 62; Ždralović, 2002, s. 132).

Fetva ve Vaazları: Eyyûbîzâde'nin fetvaları farklı kişilerce yazma mecmualara kaydedilmiştir. İbrahim Opijačın kaydettiği 10 fetva, AH Ktp. 747 nr.da kayıtlı yazmanın 3a-4b varakları arasındadır. GHB Ktp. 3871, AH Ktp. 47, 51, 73, 279 ve HAZU Ktp. 86 nr.da kayıtlı yazmalarda Eyyûbîzâde'ye ait fetvalar bulunmaktadır (Hasandedić, 1974, s. 62, 67; Ždralović, 2002, s. 132).

Eyyûbîzâde'nin verdiği vaazlar da kaydedilmiştir. AH Ktp. 99 nr.da kayıtlı yazmanın 49b ile 54b varakları arasında Eyyûbîzâde'ye ait Cuma ve bayram namazlarında verdiği hutbeler vardır (Hasandedic, 1974, s. 61-62).

Eyyûbîzâde'ye Yanlışlıkla Nispet Edilmiş Eser: Süleymaniye Ktp. Celal Ökten 131 nr.da kayıtlı basma nüshası olan Ḥıdâdu'n-Nușûl (Haşiye 'alâ Mirâti'l-Uș̂ul fì Şerḥi Mirkâati'lVușûl) adlı eser kütüphane kayıtlarında yanlışlıkla Eyyûbîzâde'ye nispet edilmiştir. Mustafa Ćeman da eserin Eyyûbîzâde'ye ait olduğunu ifade etmiştir. Ayrıca Amir Ljubović, 
Eyyûbîzâde'nin Muntecabu'l-Ḥuṣ̂ll adlı eserinin bir nüshasının Süleymaniye Ktp. Celal Ökten 131 nr.da kayıtlı olduğunu yazmaktadır (Ljubović, 1995, C. 12, s. 34; Ćeman, 2011, s. 20).

Ancak eser incelendiğinde 1878 yılında Avusturya'nın Bosna'yı ilhak etmesi esnasında şehit düşen Mostar Müftüsü Mustafa Șı dḳ̂ Karabeg el-Mostarî tarafından 1292/1875-76'da telif edilen bir eser olduğu görülmüştür. Eser, 1316/1898'de Saraybosna Državna Štamparija matbasında 532 sayfa olarak basılmıştır (el-Mostarî, 1316/1898, s. 1; Handžić, 1992, s. 188; Šabanović, 1973, s. 587-88).

\section{BÖLÜM: MUSTAFA EYYÛBÎZÂDE EL-MOSTARÎ'NIIN ARAP DİLİ VE BELAGATINA DAİR ÜÇ RISSALESININN TAHKIKİ}

\section{Risâle fî Beyâni İctimâ'i'l'İsti'âreti'l-Tebe'iyye me'a't-Temsîlliyye}

Eserin Nüshaları: Tek varaklık bu eserin ikisi de müellif hattı nüshası olmak üzere tespit edilen iki nüshası vardır:

1. HAZU Ktp. 1410/1 nr.da 1b-2b varakları arasında kayıtlıdır. Müellif hattı nüshasıdır (Ždralović, 1981, s. 132). Tahkikte bu nüsha için kütüphane adının baş harfi olan (ك) rumuzu kullanılmıştır.

2. GHB Ktp. 4615/5 nr.da kayıtlı olup katalogda yazmanın 17b-18a varakları arasında olduğu yazmaktadır. Müellif hattı nüshası olup yazmadaki eserlerin hepsini Eyyûbîzâde istinsah etmiştir (Fajić, 1999, C. 5, s. 289, 291).

Ancak nüshayı temin ettiğimizde eserin olduğu varağının kopması nedeniyle 8a varağındaki Risâle fì Âdâbi'l-Bậs adlı eserin olduğu yere yanlışlıkla konularak tarandı̆̆ 1 görülmüştür. Tahkikte bu nüsha için kütüphane adının baş harfi olan (غ) rumuzu kullanılmıştır.

Eserin İçeriği: İstiâre, Arap belagatında teşbihe mübalağa sağlamak ve bir şeyi kapalı bir biçimde teşbih etmek için hakiki manayı kastetmeye mâni bir karineye dayalı olarak gerçek mana ile mecazi mana arasındaki benzerlikten faydalanılarak bir ifadenin gerçek anlamı dışında kullanılması anlamına gelmektedir (es-Sekkâkî, 1987, s. 369; el-Kazvinî, 2003, s. 212; et-Teftâzânî, 2013, s. 578; el-Hâşimî, 1999, s. 258; Bolelli, 2016, s. 90; Pala \& Durmuş, 2001, C. 23, s. 315-317).

İstiâre, benzetilen (musteâr leh) ifade ile benzeyen (muste'âr minh) ifadenin zikredilip zikredilmemesine göre değişik adlarla adlandırılmıştır. Sadece benzetilenin zikredildiği istiâreye tasrihiyye (açı), sadece benzeyenin zikredildiği istiâreye ise mekniyye (kapalı) denilmiştir. Ayrıca mesel (atasözü) gibi sembolik anlatımlarda benzeyenin zikredilmeyip benzetilenin birden çok özelliğinin terkib olarak zikredildiği istiâreye temsiliye denilmiştir. Diğer taraftan istiâre, benzeyen ifadenin yapısına göre asliyye ve tebeiyye olmak üzere iki kısma ayrılmıştır. İfade, cins ve camid (türemeyen) olursa asliyye, cins olmayan ve muştak (türeyen) isim, fiil ve harf olursa tebeiyye olarak adlandırılmıştır. Bu istiâre çeşidine tebeiyye denilmesinin sebebi türeyen kelimelerin türediği kaynaklara, harflerin manalarının ise taalluk ettiklerine tabi olmasındandır. Harflerin manaları cuzî olup kendi başına benzeyen ve benzetilen anlamı taşıyan kullî mana aracilığı olmadan harflerde istiâre tasavvur edilemez (es-Sekkâkî, 1987, s. 374, 378, 380; el-Kazvinî, 2003, s. 213, 214, 226; et-Teftâzânî, 2013, s. 593-594, 597; el-Hâşimî, 1999, s. 266; Bolelli, 2016, s. 92, 105, 134; Pala\&Durmuş, 2001, C. 23, s. 315-317). 
Eser, Emir Timur'un sarayında Numan el-Harezmî'nin hakemliğinde Sadeddin etTeftâzânî (ö. 792/1390) ve es-Seyyid eş-Şerîf el-Curcânî (ö. 816/1413) arasında geçen meşhur

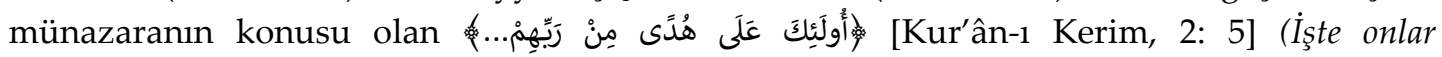
Rab'lerinden (gelen) bir doğru yol üzeredirler...) ayetinde عَلَّ kelimesinde istiâre-i temsiliyye ve istiâre-i tebeiyyenin bir arada bulunup bulunamayacağına dair ihtilafı ele almaktadır.

el-Âlûsî, et-Teftâzânî'nin mağlup ilan edildiği bu münazarayı Sibeveyh'in Yahyâ elBermekî'nin meclisinde el-Kisâî'ye karşı haksız bir şekilde mağlup ilan edilmesine benzetmiştir. Bu münazarada ele alınan ihtilaf daha sonra gelen âlimler arasında uzun yıllar boyunca devam etmiş ve âlimlerin çoğunluğu et-Teftâzânî'nin görüşünü haklı bulmuştur (el-Âlûsî, 1314/1896-97, s. 109-15; el-Âlûsî, 1353/1934-35, C. 1, s. 124; Özen, 2011, C. 40, s. 303).

Eyyûbîzâde, et-Teftâzânî'nin ez-Zemahşerî (ö. 538/1144)'ye ait el-Keşşâf adlı eserde geçen ifadelerinden hareketle istiâre-i temsiliyede benzemenin iki tarafının terkib olmak zorunda olmadığını, istiâre-i tebeiyyenin iki tarafı gibi müfred de olabileceğini, bu

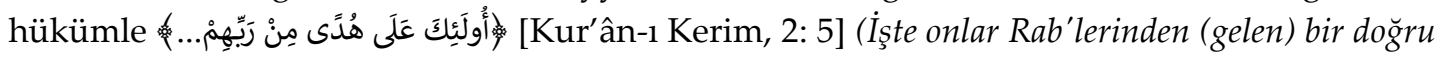
yol üzeredirler...) ayetinde على kelimesinde istiâre-i temsiliyye ve istiâre-i tebeiyyenin bir arada bulunmasına cevaz verdiğini ifade etmiştir.

et-Teftâzânî, Hâş̧iyetu'l-Keşşâf adlı eserinde görüşlerini şöyle açıklamaktadır: ezZemahşerî'nin bahse konu ayet hakkında ومعنى الاستعلاء مثل (üstte olma manasi temsilidir) açıklamasından hareketle عelimesi, harf-i cer olmasından dolayı istiâre-i tebeiyyedir ve benzeme ilgisinin çeşitli yönlerden oluşmasından dolayı da istiâre-i temsiliyyedir. Çünkü müminlerin halleri هدى (hidayet) konusunda bir şeyin üzerinde olan veya üzerine binen kişinin yerleşmesine benzetilmekte ve hidayet, onlar için binilen şey yerine kullanılacak kelimenin sıfatı şeklinde gelmiştir. Aynı şekilde أَراكَ تُقدَّمُ رِجْلاً وتُوََِْرُ أُخْرى (Seni bir ayağını öne atarken diğerini geri çeker bir halde görüyorum) örneğindeki kelimelerin tekilinde istiâre olmayıp cümlenin hepsinde istiâre-i temsiliyye vardır (et-Teftâzânî, yz. 190, 28a).

et-Teftâzânî, karşı görüşü savunanların öne sürdügü harf ile yapılan istiâre-i tebeiyyeye ait benzemenin taraflarının murekkeb olması gerektiğinden istiâre-i temsiliyye ile birarada gelemeyeceği ile harfi cerrin manasının bağlı olduğu kelimenin sadece müfred olabileceği şeklindeki gerekçeler hakkında ilgili temsilin yapısının bir durumun tamamını başka bir durumun tamamına benzetme olduğunu ve birden çok şeyden oluşması gerektiğini, bu durumun da harfin manasına bağlı olması ile çelişki oluşturmadığını ifade etmiştir (et-Teftâzânî, yz. 190, 28a).

Müellif, es-Seyyid eş-Şerîf el-Curcânî'nin bu görüş hakkında istiâre-i temsiliyyenin terkib olması, istiâre-i tebeiyyenin ise masdar ve harflerden meydana geldiği için müfred olması gerektiğini, bu çelişki nedeniyle et-Teftazani'nin على kelimesinde istiâre-i temsiliye ve istiâre-i tebeiyyenin birarada olduğu görüşünün aksine bu iki istiârenin bir arada bulunamayacağını ifade ettiğini ve Hâş̧iye 'ale'l-Mutavovel adlı eserinde et-Teftazani ile aralarında geçen münazaradan bahsettiğini (el-Curcânî, 2007, s. 381) söylemektedir.

Daha sonra müellif, el-Curcânî'nin bu ayetteki istiâre hakkında yazdığı 3 farklı ihtimali aktarmaktadır: İlk ihtimale göre الهدى (hidayet) kelimesinin المركب (binek)'e benzemesi ile istiâre-i mekniyye oluşacağı, ikinci ihtimale göre muttakilerin hidayete sarılı olmaları, binicinin üstte ve hâkim bir şekilde olmasına benzemesiyle على kelimesinde istiâre-i tebeiyye oluşacağı̆, üçüncü ihtimale göre المتقي والهدى وتمسّك به وله kelimelerinden oluşan yapının الراكب والمركوب واعتلائه (binici, binek ve hâkim olarak üstte olma) 
kelimelerinden oluşan yapıya benzemesiyle istiâre-i temsiliyye oluşacağıdır (el-Curcânî, 2007, s. 384).

Ardından müellif, el-Curcânî'nin konu ile ilgili şu görüşlerini aktarmaya devam etmektedir: İkinci yapıya delalet eden lafızların hepsi, birinci yapı kastedilerek söylenmesi gerekir. Ve böylece bu lafızların hepsi çok çeşitli yönlerden oluşan bir istiâre-i temsiliye olacaktır. Bu şekilde bu lafızlarda bir değişiklik olmayacaktır. Bu durum, تُقدِّم رِجْلاً وتؤخِّرُ أُخْرى cümlesinde oluşan istiâre gibi olacaktır. Böylece تقدّم kelimesinde istiâre-i tebeiyye olmadığ1 gibi kelimesinde de istiâre-i tebeiyye olmayacaktır. ez-Zemahşerî̀nin bu lafızlarda (ayetin lafızları) sadece عelimesini kullanmasının sebebi ise onun, bu durumların (binici, binek ve hakim olarak üstte olma) temel manasını kapsamasıdır (el-Curcânî, 2007, s. 385).

Müellif, et-Teftâzânî'nin de tercihi olduğu gibi eğer bu lafızlar arasından sadece على kelimesi ile yetinilirse terkibin benzemenin kendisinde değil benzeme tarafının kaynağında oluşacağını ve her iki istiârenin bir arada olabileceğini, تقدّم örneğinde açıkça istiâre-i tebeiyye olduğunun söylenmemesinin sebebi ise benzemenin hem kendisinde hem de kaynağında terkib oluşturulması olduğunu, ayette istiare-i temsiliyye olduğu kabul عelimesinde de istiâre-i tebeiyye olduğunun açıklanmaması, على edildikten sonra kelimesinde istiâre-i tebeiyye olmadığı anlamına gelmeyeceğini ifade etmiştir.

Müellif ayrıca el-Curcânî'nin "عelimesinin bu terkibte tek başına istiâre edilmesinin doğru bir yönü yoktur. Çünkü bu terkib, ne عelimesinin manası ne de onun manasına bağl bir şey değilken ondan istiâre nasıl mümkün olabilir ki?" (el-Curcânî, 2007, s. 385) sözünün doğru olmadığını söylemektedir.

Daha sonra müellif, el-Curcânî'nin, "Bazı lafızlarla yetinmenin faydası ibarenin kısalması ve bir yönden tebeiyye diğer bir yönden ise temsiliyye olma ihtimallerinin çoğalmasıdır. Ama istiârenin, terkibin bütünlü̆̆̈̈nde olduğu söylenirse o zaman sadece istiâre-i temsiliyye ihtimali olurdu" (el-Curcânî, 2007, s. 389) sözü hakkında ise âlimlerin görüşlerinde istiâre-i tebeiyye ile istiâre-i temsiliyye aynı kelimede olamayacağına dair net bir ifade yokken neden bir arada bulunamayacağını sorarak eleştiri getirmekte ve ez-Zemahşerî̀nin sözünün bu durumun caiz olduğuna işaret ettiğini söylemektedir.

Müellif, Şerafeddin eț-Tîibî (ö. 743/1343), Ekmeleddin Muhammed el-Babertî (ö. 786/1384) ve 'Imâduddin Yahya b. el-Ḳâsım el-Alevî el-Yemenî (ö. 750/1349)'nin iki istiârenin bir arada oluşmasına cevaz verdiğini, âlimlerin ittifakı ile bu konuda kati bir delil olduğunu söyleyerek risalesini tamamlamıştır. Konu hakkında bazı âlimlerin görüşleri ise şöyledir:

Şerafeddin et-Ṭ̂ibî, Hâş̧iye ale'l-Keşşâf (Futûhu'l-Ġayb) adlı eserinde bahse konudaki istiâre-i tebeiyyenin temsiliye de olduğuna delalet eden şeyin tümevarım olduğunu, bu iki istiârenin bir arada olmasına bir örnek olarak es-Sekkâkî'nin el-Miftâh adlı eserinde لعل kelimesinde istiâre-i tebeiyye ve istiâre-i temsiliyyenin bir arada olmasının cevazına işaret ettiğini ifade etmiştir (et-Tîbî, 2013, C. 2, s. 109).

Alaaddin Musannifek el-Bestâmî (ö. 875/1470), Ḥ̂ş̧iye 'ale'l-Muțavvel adlı eserinde etTeftazanin sözlerinin yanlış anlaşıldığı için bu ihtilafın meydana geldiğini, ez-Zemahşerî'nin el-Keş̧âf taki معنى الاستعلاء (üstte olma manası) açıklamasının istiâre-i tebeiyyeye bir işaret olduğunu, مثلاء ifadesi ile de istiâre-i temsiliyye bir işaret olduğunu ifade etmektedir (Eldih, 2019, C. 4, s. 235-38). 
Muhyiddin b. Muhammed el-Fenârî (ö. 954/1548), Ḥâşiye 'ala Şerḥi Miftahi'l- Ulûm li'sSeyyidi'ş-Şerif adlı eserinde belagat ilminin hassas bir konu olduğunu, bu ilimle uğraşmak için güçlü bir zekaya, sağlam bir zevke ve temiz bir fıtrata sahip olmak gerektiğini söyledikten sonra birkaç yönden oluşan benzemenin hem müfred hem de harf olabileceğini ifade ederek et-Teftâzânî'nin görüşünü destelemekte ve el-Keşşâf ve el-Miftâh'ta harfte istiârei tebeiyye ve temsiliyenin bir arada olmasının cevazına işaret edilidiğini belirterek büyük âlimlerin bulunduğu bir mecliste böyle bir münakaşanın fasid olduğunu belirtmiştir (Abdelaal, 2017, s. 373, 408).

\section{Eserin Tahkikli Metni:}

رسالة في بيان اجتماع الاستعارة التبعية مع التمثيلية

$$
\text { بسم الله الرحمن الرحيم }
$$

$$
\text { الحمد لوليّه والصلاة على نبيّه محمّلد وآله، وبعد: }
$$

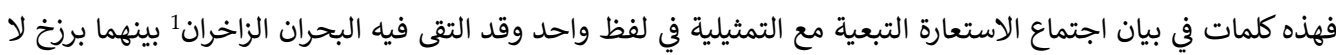

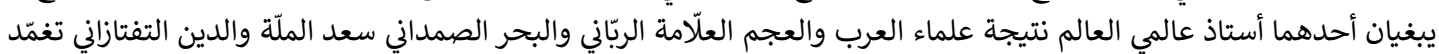

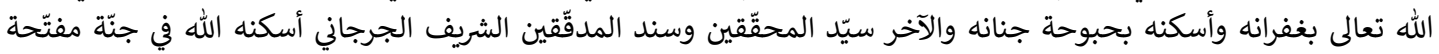

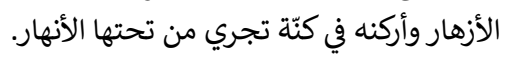

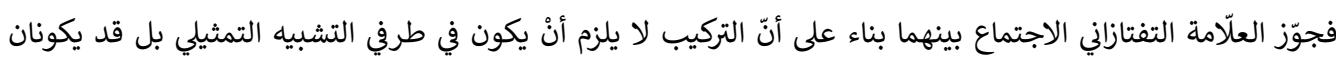

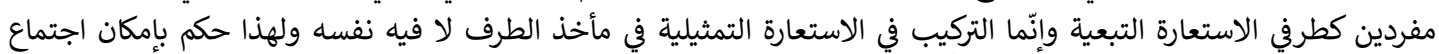

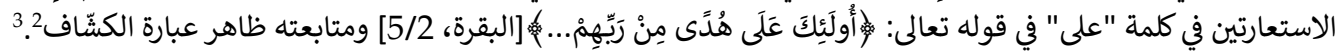

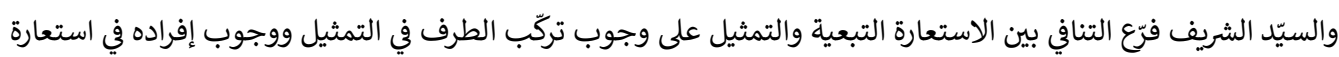

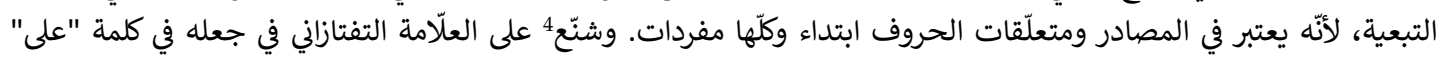

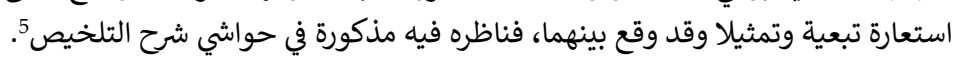

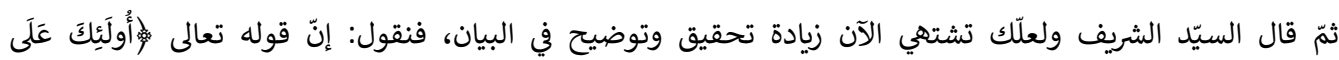

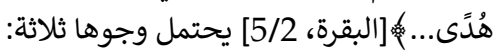

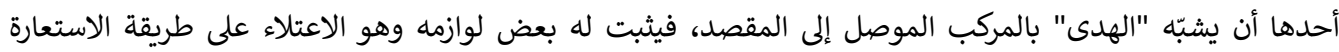

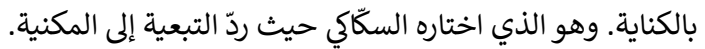

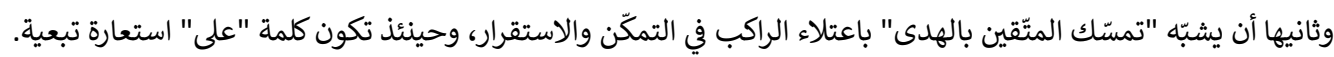

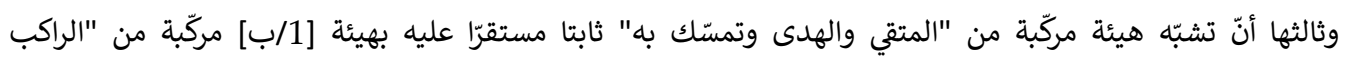

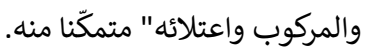

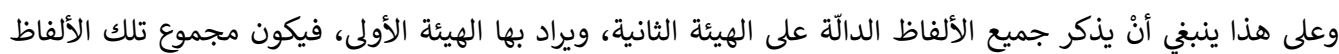

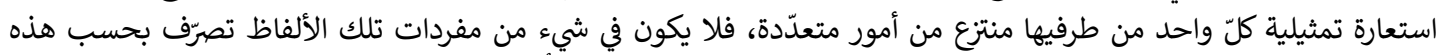

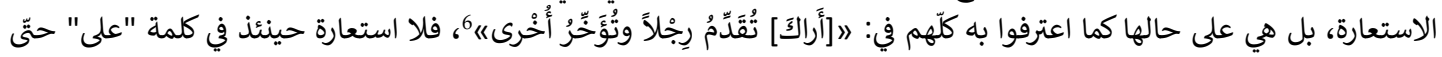

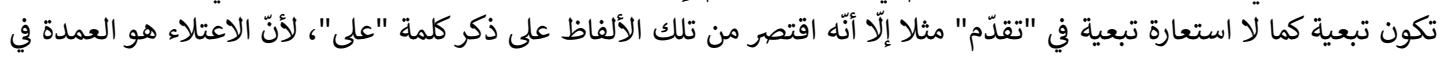

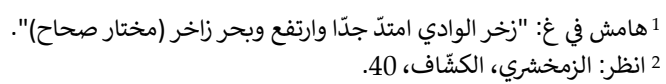

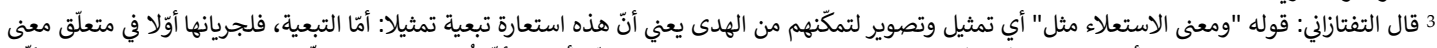

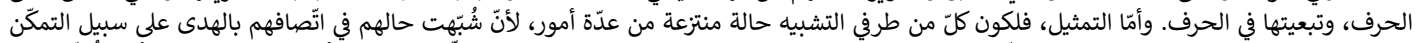

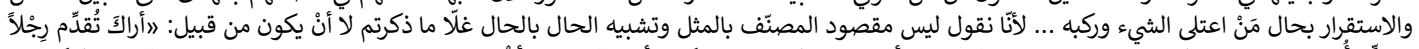

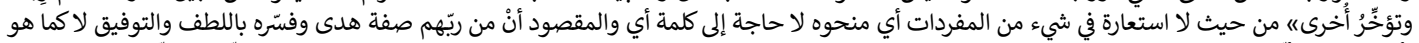

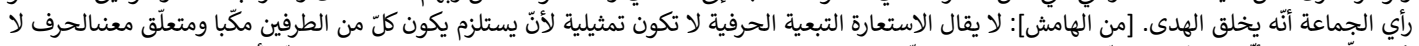

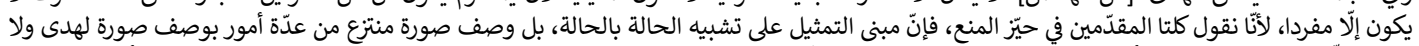

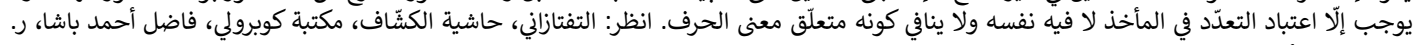

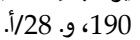

4 هامش في ك: "أي السيّد الشريف (منه)".

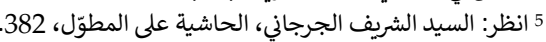

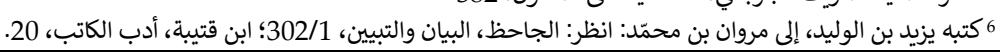

SEFAD, 2020; (44): 131-160 
الصورة المنتزعة من الراكب والمركوب واستقراره عليه، فيدلّ بمعونة قرائن الأحوال على أنّ سائر الألفاظ الدالّة على سائر أجزاء

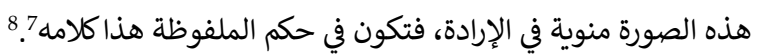

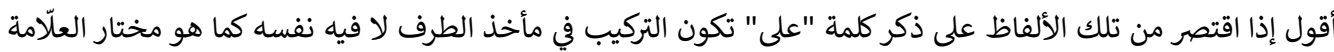

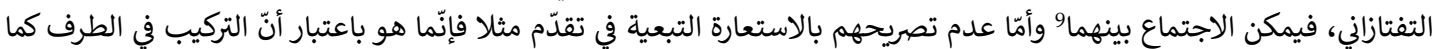

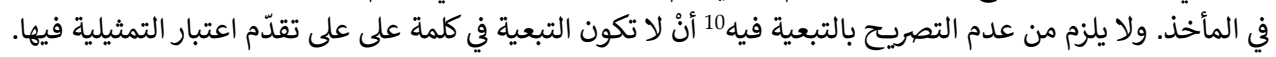

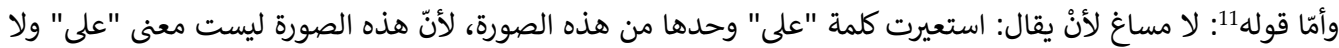

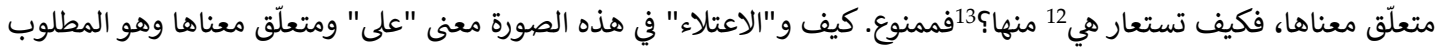

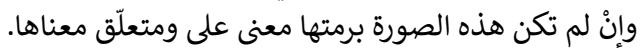

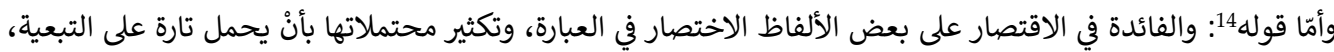

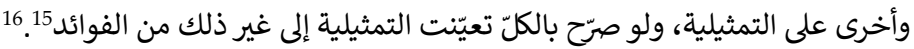

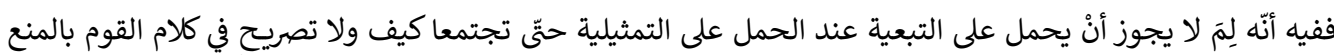

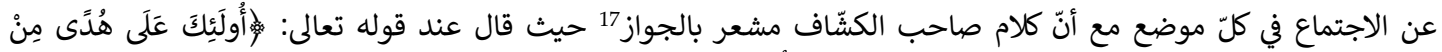

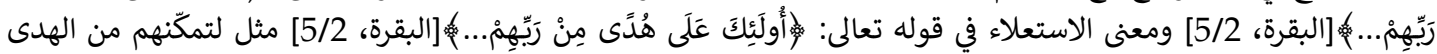

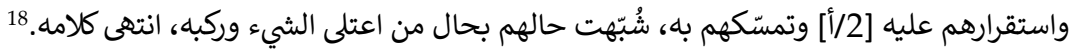

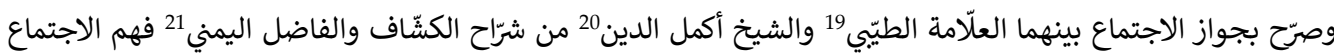

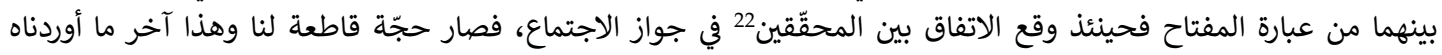

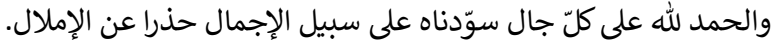

وأنا الفقير أضعف العباد مصطفى بن يوسف بن مراد غفر الله ذنوبهم وستر عيوبهم يوم التناد بحرمة محمّد وآله للأمجاد

\section{Risâle fî Kevni'l-Cumle Muțlaḳan Haberan li'l-Mubteda'}

Eserin Nüshaları: Tek varaklık bu eserin, birisi müellif hattı nüshası olmak üzere tespit edilen iki nüshası vardır:

1. Eserin müellif hattı nüshası HAZU Ktp. 1410/2 nr.da 3a-3b vr. arasında kayıtlıdır (Ždralović, 1981, s. 132). Tahkikte bu nüsha için (ك) rumuzu kullanılmıştır.

2. Eserin, GHB Ktp. R-4611/2 nr.da 211b-212a varakları arasında kayıtlı bir nüshası daha vardır. Eser, kütüphane kayıtlarında ar-Risâlâ fî Kawn al-Ğumla Muțlaqan Habaran li alMubtada' şeklinde kaydedilmişir (Jahić, 1999, C. 6, s. 375). Tahkikte bu nüsha için (غ) rumuzu kullanılmıştır.

$$
\begin{aligned}
& 7 \text { هامش في غ: "أي كلام السيّد الشريف (منه)". }
\end{aligned}
$$

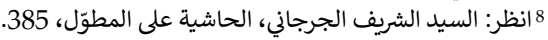

$$
\begin{aligned}
& \text { 9 هامش في غ: "أي بين الاستعارة التمثيلية والتبعية (منه)". }
\end{aligned}
$$

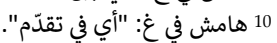

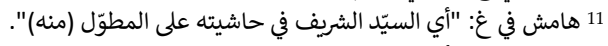

$$
\begin{aligned}
& 12 \text { هامش في غاغ: "أي على (منه)". }
\end{aligned}
$$

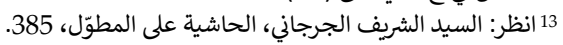

$$
\begin{aligned}
& 14 \text { هامش في غ : "أي السيد الشريف (منه)". } \\
& 15 \text { هامش في غا: "مثل كونه عمدة (منه)". }
\end{aligned}
$$

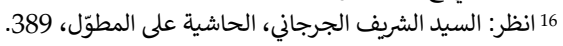

$$
\begin{aligned}
& 17 \text { هامش في غ: "أي جواز الاجتماع بينهما (منه)". }
\end{aligned}
$$

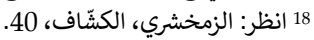

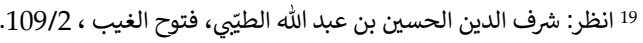

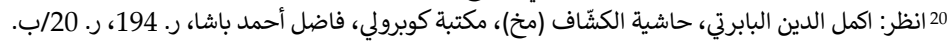

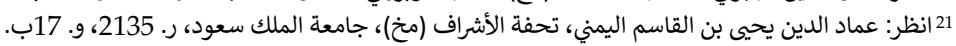

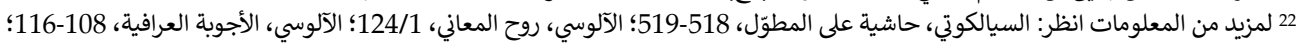
E. Elbera (2019). Musannifek'in haşiye 'ale'l-mutavvel adlı eserinin tahkiki (C. 4.) (Yüksek lisans tezi). Erişim Adresi: https://tez.yok.gov.tr/UlusalTezMerkezi/ s. 235-38; F. E. B. Abdelaal (2017). Haşiye ala şerhi miftahu'l-ulum li's-Seyyidi'ş-Şerif adlı eserinin tahkiki (Yayımlanmamış yüksek lisans tezi). Selçuk Üniversitesi, Konya. s. 373, 408. 
Eserin İçeriği: Arap belagatında söz, "haber" (bildirme) ve "inşâ" (istek) olmak üzere ikiye ayrılır. İhbarî ifade, sözün söylendiği anda mevuct olan veya mevcut olacak bir şeye delalet için kullanılırken inşâ̂i ifade, sözün söylendiği anda mevcut olmayıp anlamını telaffuzu ile oluşturan ifade için kullanılmaktadır. Haber, doğru veya yalan ihtimali taşırken inşâ, doğru veya yalan ihtimali taşımaz. İnşa cümlesi, bir isteğe delalet eden "taleb̂̂ inşâ" ve bir isteğe delalet etmeyen "gayri talebî inşâ" olmak üzere ikiye ayrilır. Talebî inşấ'nın çeşitleri emir, nehy, istifham, temenni ve nida gibi ifadeler iken gayri talebî inşấ' nın çeşitleri mukarebe fiilleri, medh ve zem fiilleri, taaccüb, yemin, akd sigası, lealle, rubbe ve kem-i haberiyye gibi ifadelerdir (es-Sekkâkî, 1987, s. 164-165; el-Kazvinî, 2003, s. 108; et-Teftâzânî, 2013, s. 406; Bolelli, 2016, s. 229; Görgün, 2000, C. 12, s. 339).

Eser, ilk risalede ele alınan konu gibi et-Teftâzânî ve el-Curcânî arasındaki ihtilaflı birçok meseleden biri olan inşâ cümlesinin mubtedaya te'vil (gizli anlamını ortaya çıarma) olmadan haber olup olamayacağı hakkındadır.

Bu ihtilaf, Mestcizade Abdulah Efendi (ö. 1150/1737)'nin et-Teftâzânî ve el-Curcânî arasındaki 24 ihtilafa yer veren İhtilâfu's-Seyyid ve's-Sadeddin adlı eserinde 18. ihtilaf olarak verilmiştir (Mestcizade, 1278/1861, s. 38-39).

Eyyûbîzâde eserine risalenin konusuna dair: "Bu kelimeler, cümlenin stnırlama olmadan mubtedanın haberi oluşuna dair tercih edilen görüşün beyanı hakkındadır" anlamındaki cümle ile giriş yapmış ve hemen arkasından bu konu hakkında Sadeddin et-Teftâzânî (ö. 792/1390) ve es-Seyyid eş-Şerîf el-Curcânî (ö. 816/1413) arasında ihtilaf olduğunu ifade etmiştir.

Müellif, et-Teftâzânî'nin meşhur olan görüş te'vil ile olması iken inşâ cümlesinin mubtedaya te'vilsiz haber oluşuna cevaz verdiğini, el-Curcânî'nin ise Şerḥu'l-Miftâh'̣'da: "Mubtedaya ait haberin, mubtedanın hallerinden biri olduğunun ve aralarında nispet oluşturulmuş olsun veya olmasin mubtedaya nispet edildiğinin anlaşılması gerekir. Şüphesiz (زيدّ) örneğindeki (اضربْ) (اضربْ زيدا) örneğğindeki gibi belirgin bir şekilde olursa veya (اضرئه) sözünden onun dayak yemek için emredilmeyi hak ettiğgi te'vil edilirse bu sözün (زيد)'e ait bir hal olduğu anlaşılmış olur." sözüyle et-Teftâzânî'ye itirazda bulunduğunu söylemektedir.

et-Teftâzânî, Şerḥu'l-Miftâh' da talebî ve gayri talebî inşâ cümlesinin birçok sözde haber olarak geldiğini, âlimlerin bahsettiği cümlenin te'vil edilmesi hususunun zorunlu olmadığını, bilakis mubtedayı mahsus yapan medh ve zem cümlesi ile dua cümlesinde

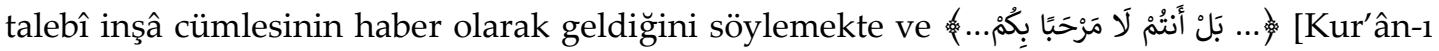
Kerim, 38: 60] (...Hayır, size rahat ve huzur olmasin...) ayeti ile أين زيد؟ متى القتال؟ كيف الحال؟ التئم vb. soru cümlelerini örnek vermektedir (et-Teftâzânî, yz. FB 48, 54b-55a).

Müellif, iki alim arasındaki bu ihtilafı ifade ettikten sonra İbnu'l-Hâcib (ö. 646/1249)'in el-Kâfiye adlı eserindeki الخبر قد يكون جملةً (Haber, cümle olabilir) ifadesinden hareketle haberin müfred olabildiği gibi cümle de olabileceğini ancak bu ifadedeki قد يكون (olabilir) ibaresindeki (قد) kelimesinin işaret ettiği üzere haberin müfred oluşunun asıl olduğunu söylemektedir.

Müellif daha sonra 'Ișâmuddîn el-İsferâyinî (ö. 945/1538)'nin Şerḥu'l-Kâfiye adlı eserinde konu hakkındaki İbnu'l-Hacib'in Ebû Bekir el-Enbârî (ö. 328/940) ve bazı Kufelilerin aksine cümleyi haber cümlesi olmakla sınırlandırmadı̆̆ına, el-Enbârî ve bazı Kufelilerin inşâ cümlesinin haber olamayacağına dair iddialarının hükümsüz olduğunun

SEFAD, 2020; (44): 131-160 
haber ve inşâ arasında zıtlık olduğunu ileri sürmelerinden anlaşıldığına, mubtedaya ait haberin inşânın kısmı olduğu konusunda yanılgıya düştüklerine ve haber lafzının belagat ve nahivde ortak kullanımasının onları yanılgıya düşürdüğüne dair açılamalarını aktarmaktadır.

Ayrıca müellif, 'Ișâmuddin el-İsferâyinî'nin na't bahsinde İbnu'l-Ḥ̂acib'in cümleyi haber için genelleştirdiğini ve böylece (زيدّ اضيُّ) inşâ cümlesine te'vilsiz cevaz verdiğini söylemektedir. Müellif, 'Ișamuddin'in neticede cümleden muradın ister haber ister inşâ olsun te'vil olmaksızın mutlak (sınırlama olmadan/genel) olduğunu söylediğini ve bu görüşünün doğru olduğunu ifade etmektedir. Ardından el-Enbârî ve bazı Kufelilerin haberin te'vil olmadan inşâ cümlesi olamayacağını söylediğini, et-Teftâzânî'nin ise mezkur ayetteki dua ifadesini ve (نعم الرجل زيدٌ) örneğindeki medh ifadesini inşâ cümlesinin haber oluşuna örnek olarak verdiğini ifade etmektedir.

el-Curcânî, Şerḥu'l-Miftâh eserinde et-Teftâzânî'yi kastederek bazı âlimlerin inşâ cümlesinin mubtedaya te'vilsiz haber olabileceğine cevaz verdiğini, ancak âlimler arasındaki meşhur görüşün inşâ cümlesinin te'vil ile haber olabileceği yönünde olduğunu, haberin cümlede mubtedanın hallerinden biri olduğunun ve ona ait olduğunun anlaşılması gerektiğini söyledikten sonra bahsi geçen ayetin buna göre değerlendirilmesi gerektiğini ifade etmiştir (Çelik, 2009, s. 139).

Ancak er-Raḍî el-Esterâbâdî (ö. 688/1289) de el-Curcânî'nin aksine et-Teftâzânî gibi inşâ (talebiyye) cümlesinin haber oluşuna cevaz vermektedir. er-Raḍ̂ ayrıca el-Enbarî ve bazı Kufelilerin haberin, doğru ve yalan ihtimali taşıyan şey olduğu ve bu nedenle haberin, talebiyye (inşâ) cümlesi olamayacağına dair görüşlerinin doğru olmadığını, haber lafzının bu yanlış anlamaya sebep olduğunu, nahivcilerin nezdinde haberden muradın doğru veya yalan ihtimali taşıyan şey olmadığını ve (أزيدٌ عندك؟) örneğinde doğru ve yalan ihtimali taşımamasına rağmen zarfı haber olarak tanımladıklarını, onlara göre haberin İbnu'lHacib'in tarif ettiği gibi olduğunu ve mezkur ayetin talebiyye cümlesinin haber oluşuna delil olduğunu ifade etmektedir (er-Radi, 1993, C. 1, s. 267).

Müellif, inşâ cümlesinin te'vil ile haber olabileceğini düşünen âlimlere göre (بل أنتان) sözünün (لا مرحبا بكم) hakkında ve (نعم الرجل) sözünün de hakkında söylenmiş anlamına geleceğini ve bunun ise zorlama bir değerlendirme olduğunu ifade etmektedir.

Müellif, Molla Abdulgafûr el-Lârî (ö. 912/1506)'nin Nureddin Mollâ Câmî (ö. 898/1492)'ye ait el-Fevấidu'ḍ-Diyâiyye üzerine yazdığı haşiyesinde İbnu'l-Ḥ̂acib'in "haber, cümle olabilir" ifadesi ile haberi, haber cümlesi olmakla sınırlandırmadığını ve inşâ cümlesinin kasem cümlesi olsa bile mubtedaya haber olabileceğine dair nahivcilerin genelinin görüşünü takip ettiğini ve onlardan bazılarının faydasız şeylerle softalık yapanları engellediğini ve el-Curcânî'nin haberin mubtedanın hallerinden birisi olması gerektiği ve inşânın ancak te'vil ile onun hallerinden biri olacağı iddiasında tutucu olanları takip ettiğine dair görüşlerini aktarmaktadır.

Müellif, et-Teftâzânî'nin açılamalarının âlimlerin genelince tercih edilden görüş haline geldiğini, es-Seyyid eş-Şerîf el-Curcânî'nin bir görüşün tercih edilen görüş olması akıl gereğince peşinden gitmeyi gerektiren bir husus olmadığına dair düşüncesi ile mezkur ayeti te'vil ederek örnek vermesinin zorlama bir değerlendirme ve kibir olduğunu ifade ederek eserini sonlandırmaktadır. 


\title{
Eserin Tahkikli Metni:
}

\author{
رسالة في كون الجملة مطلقا خبرا للمبتداء \\ بسم الله الرحمن الرحيم \\ الحمد لله ربّ العالمين والصلاة على سيّد المرسلين محمّد وآله وصحبه أجمعين. وبعده:
}

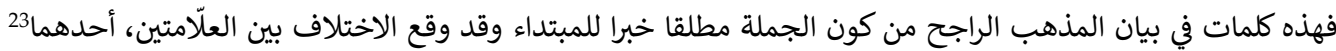

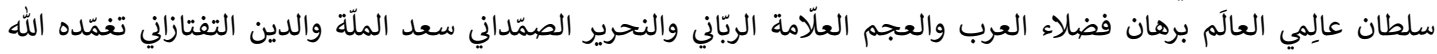

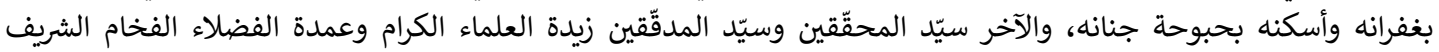

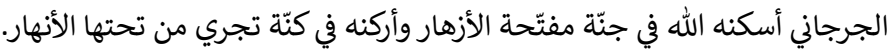

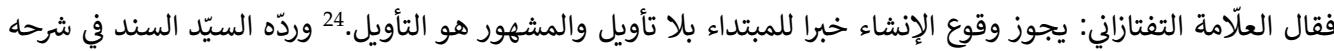

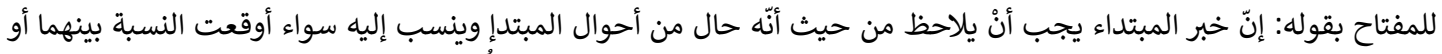

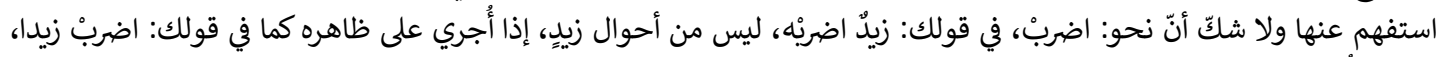

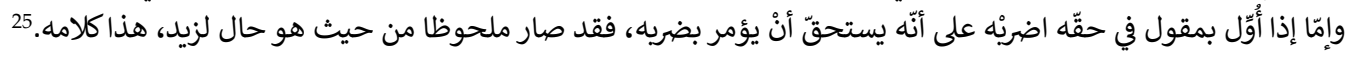

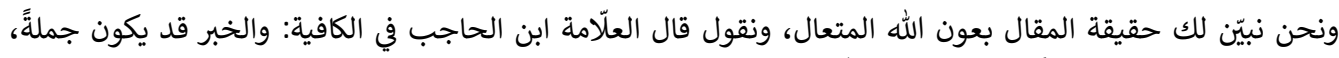

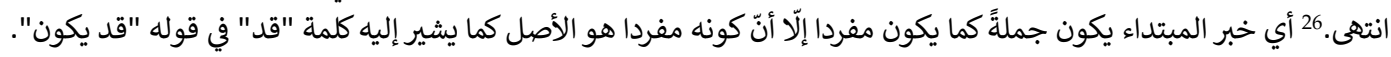

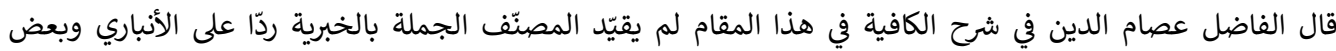

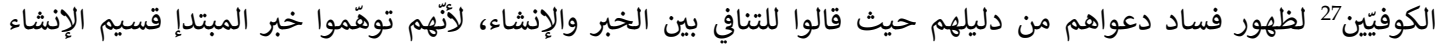

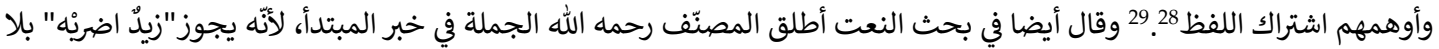
تأويل، انتهى.

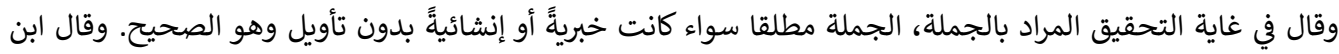

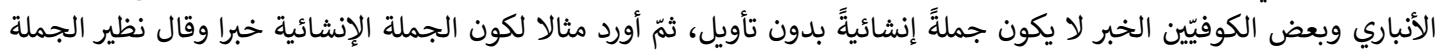

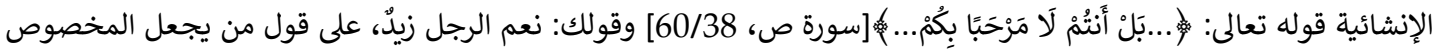

بالمدح مبتدأ متقدّم الخبر.

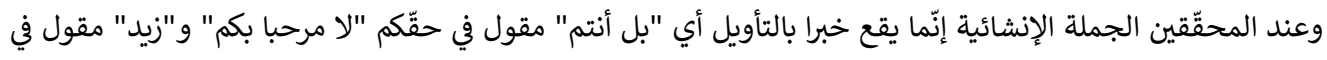

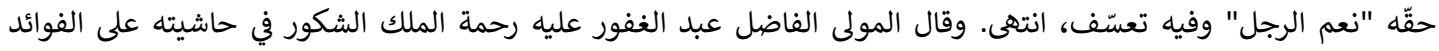

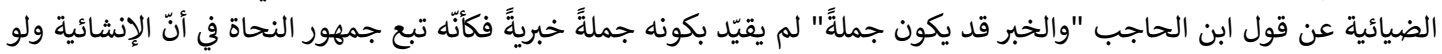

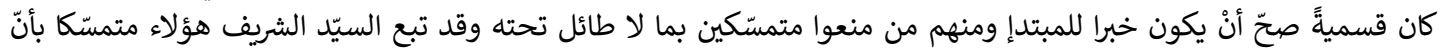

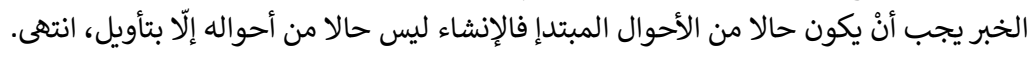

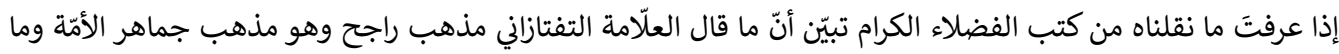

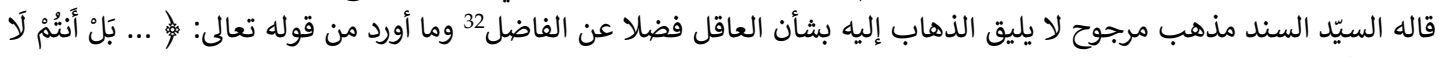

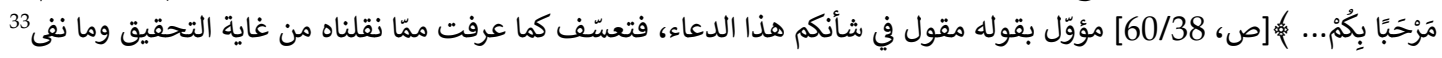

23 صح في هامش غ: "وقع الاختلاف بين العلّامتين أحدهما".

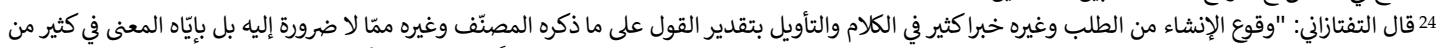

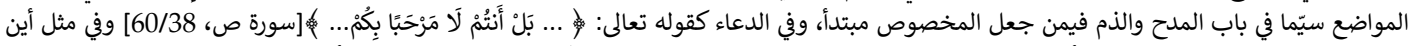

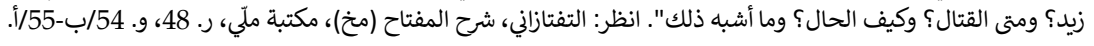

25 انظر:

Y. Çelik (2009). es-Seyyid eş-Şerif el-Cürcani'nin "el-misbah fi şerh el-miftah" adlı eserinin tahkik ve tahlili (edisyon kritik) (Doktora tezi). Erişim Adresi: https://tez.yok.gov.tr/UlusalTezMerkezi/ s. 139.

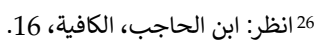

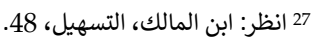

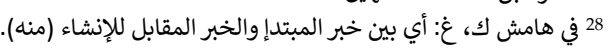

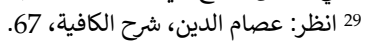
30 انظر: عصام الدين، شرح الكافية، النية، 170

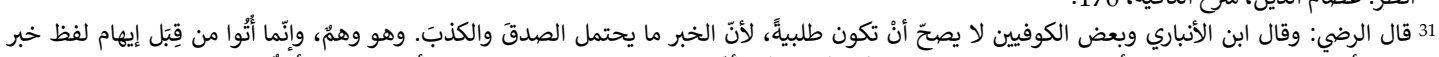

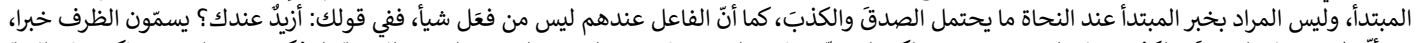

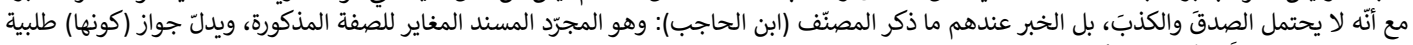

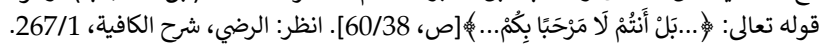
32 في هامش ك، غُ غأ أي السيّد السند (منه).

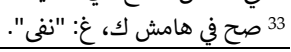

SEFAD, 2020; (44): 131-160 


$$
\text { الجمدّة خنهار إلّا مكابرة غفر الله له ولنا ولسائر المسلمين على أنّه لو قدّر مقول كان الخبر مفردا وليس كلامنا فيه بل الكلام في كون }
$$

\section{Risâle fî mâ Kâle el-Ḳuhistânî 'an I'râbi 'İbareti "Kitâbi'ț-Ṭahâre":}

Eserin Nüshası: Eserin bilinen tek nüshası HAZU Ktp. 1410/3 nr.da 4a-4b varakları arasında kayıtlı olup müellif hattı nüshasıdır (Ždralović, 1981, s. 132).

Eserin İçeriği: Eyyûbîzâde, risalenin mukaddimesinde dostlarının Şemseddin Muhammed b. Husâmiddîn el-Kuhistânî (ö. 962/1555)'nin Burhânuşşerî‘a Mahmûd b. Șadruşşerî‘a el-Evvel (ö. 693/1293'ten sonra)'in Vikâyetu'r-Rivâye fì Mesâ'ili'l-Hidâye adlı eserine Șadruşşeri'a eś-Sânî (ö. 747/1346)'nin yazdığ en-Nukâye isimli muhtasarına yazdığ Cami 'u'r-Rumûz Şerḥu Muhtașari'l-Vikâaye adlı şerhinden bazı açıklamalar istemeleri üzerine bu varağı yazdığını ifade etmektedir.

Eyyûbîzâde, risalesinde ḳ̂ale-eḳ̂ulu metodu ile konuyu açıklamaktadır. el-Ḳuhistânî, el-Vikâye adlı eserin musannifinin söylediği كتاب الطهارة ibaresinin murekkeb olmadığ1 için aslının sükun olduğunu ifade etmiştir. Eyyûbîzâde, bu söz ile كتاب kelimesindeki باء harfinin mebni olduğu için sakin olduğunu, aslının sükün üzere mebni olduğunu, mu 'rab olmadığını ve bunun da İbnu'l-Hâcib'in el-Kâfiye adlı eserindeki "İsim, mu 'rab ve mebni olarak ikiye ayrilır. Mu'rab isim, temelinde mebniye benzemeyen murekkebtir" görüşü üzerine olduğunu, murekkeb ifadesinden kastın kendisinden başka bir kelimeye âmil olabilecek bir terkib oluşturan isim olduğunu, burada ise terkib olmadığını ve bu nedenle İbnu'l-Hâacib (ö. 646/1249)'in görüşüne göre mebni olduğunun ifade edildiğini açıklamaktadır.

el-Ḳuhistânî, daha sonra باء harfinin iki sakin harfin karşılaşmasından dolayı kesre ile harekelenebileceğini söylemiştir. Eyyûbîzâde, bu söz ile sakin harfin harekeleneceği zaman kesre ile harekelendiğini ve böylece ifadenin باءٍ الطهارة harfinin kesreli hali olan olacağının ifade edildiğini açıklamaktadır.

el-Ḳuhistânî, باء harfinin hemzeden nakille fetha ile de harekelenebileceğini söylemiştir. Eyyûbîzâde, bu söz ile hemzeden nakille temelde sakin olan باء harfinin fetha ile harekelenebileceği, böylece ifadenin باء harfinin fethali hali olan كتاب الطهارة olacağı çünkü fethanın harekeler arasında en hafif harf olduğunun ifade edildiğini açıklamaktadır. Eyyûbîzâde, eğer bu kelime iki şekilde diğer kelime ile terkib oluşturuyor ve bu nedenle mu'rab olması gerekir denilirse mu'rabtan kastedilen, başka bir kelime ile ona amel edecek şekilde bir terkib oluşturan kelimedir. Burada ise muzaf olarak muzafun ileyh ile bir araya gelse de amel edecek bir terkib şeklinde değildir ve غلام زيلام örneğindeki gibi sadece muzaftır. Bu nedenle mebnidir, çünkü diğer kelime ile amel edecek şekilde bir terkib oluşturmamıştır diye cevap vereceğini ifade etmektedir.

el-Ḳuhistânî, باء harfinin hazifle beraber damme ile de harekelenebileceğini söylemiştir. Eyyûbîzâde, bu söz ile باء harfinin hazfedilmiş mubtedadan takdir edilerek damme ile harekelenebileceği ve sözün هذا الكتابُ الطهارة olacağ1 veya hazfedilmiş haberden takdir edilerek damme ile harekelenebileceği ve sözün bu sefer هذبانُ الطهارة هذابُ olacağı, hazifle beraber hareke takdir edildiği zaman muzafın mu'rab bir kelime haline geleceği, çünkü manevi amil olarak diğer kelimeye amel eden bir kelime konumunda terkib oluşturacağının ifade edildiğini açıklamaktadır.

34 في هامش ك، غ: أي من السيد السند (منه). 
Eyyûbîzâde, el-Ḳuhistânî'nin sözleri ile ilgili açıklamanın bu kadar olduğunu ancak konu ile ilgili şu 3 hususu zikretmenin faydalı olacağını söylemektedir:

Birinci olarak el-Ḳuhistânî, üçüncü ihtimal olan hazifle beraber damme ile harekelenme ihtimalini en son söyledi, çünkü ilk iki ihtimale göre daha zayıftır.

İkinci olarak İbnu'l-Hişâm (ö. 218/833)'ın Ebû Muhammed el-Vâsıṭ̂ (ö. 626/1229)'den naklettiği görüş olan eğer konu mubteda ve haberin hazfi arasında değerlendirilecekse mubtedanın hazfi daha evladır. Çünkü haber, sözün özüdür.

Üçüncü olarak ibarenin dammeli olmasına cevaz verilmesi nahiv kuralları açısından değerlendirildiğinde eğer durum fiilin hazfi ve ma'mûlun kalması ihtimali ile mubtedanın hazfi ve haberin kalması ihtimali arasında ise ikinci ihtimal daha evladır. Çünkü mubteda, haberin kendisidir. Yani hazfedilen şey kalan şeyin aynısıdır. Ve böylece hazfin sanki hiç yapılmamış gibi olacağını ifade etmektedir.

Müellif bu değerlendirmelerle tek varaklık bu risalesini tamamlamaktadır.

\section{Eserin Tahkikli Metni:}

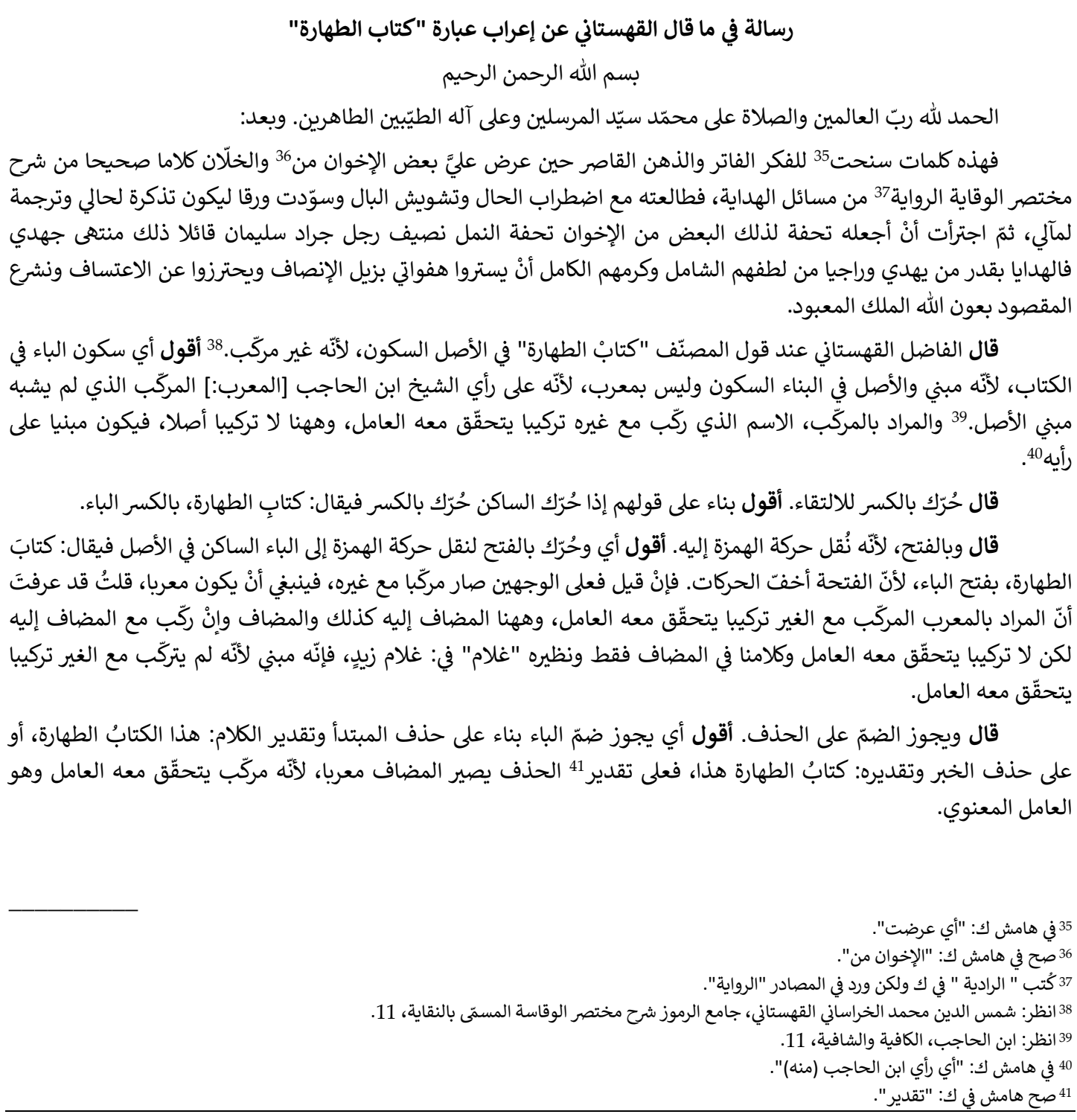

SEFAD, 2020; (44): 131-160 


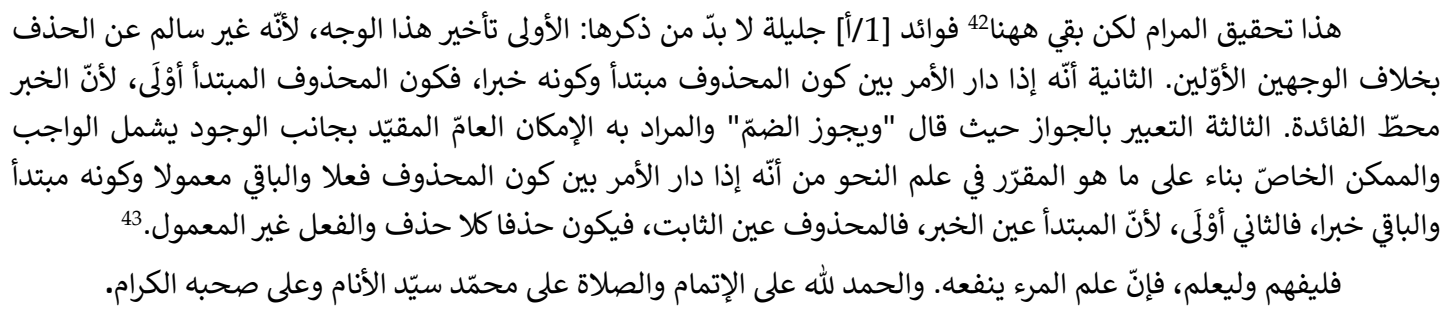

\section{SONUÇ}

Mustafa b. Yûsuf Eyyûbîzâde el-Mostârî, hakkında daha önceden yapılan çalışmalarda hayatı ve eserleri hakkında bilgiler verilmiştir. Bu çalışma ile bu kaynaklarda geçen Eyyûbîzâde'ye ait eserler ve eserlerin kütüphanelerde bulunan nüshaları hakkında detayları çalışmada verilen yanlışlıklar ve eksiklikler düzeltilmiştir.

Bu eskikliklerin tespiti için öncelikle Eyyûbîzâde'nin Muntecabu'l-Ḥuṣ̂̂l fì Şerḥi Muntehabi'l-Uș̂ul adlı eserinde kaydettiği 24 eser, daha sonra öğrencisi İbrahim Opijač'ın Risâle fî Menâkııbi'ş-Şeyh Yûyâ adlı biyografik eserinde hocasına ait kaydettiği 27 eser karşılaştırılmıştır. Bu karşılaştırma sonucunda Eyyûbîzâde'nin kaydettiği listede yer alan

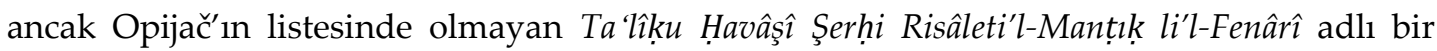
eserin olduğu görülmüştür. Ayrıca Eyyûbîzâde'nin kaydetmediği ancak Opijač'ın bahsettiği Şerh 'alấl-Luğati'l-Mevsûme bi'ş-Şâhidiyye (Hulla-i Manzûma), Şerḥu Risâle fî Âdâb li's-Seyyidi'şŞerîfi'l-Curcânî (Zubdetu'l-Âdâb), Şerḥu Dîbâceti'l-Muhtașari'l-Me 'ânî ve Nefâisi'l-Mecâlis fî̀'l$M e v ' i z a$ adlı eserlerin var olduğu görülmüştür.

Bunun yanında Eyyûbîzâde ve öğrencisi Opijač’ın bahsetmediği ancak kaynaklarda geçen Şerḥu'l-'Avâmili'l-Mie,Hâş̧iyetu'l-Muhtașar li Mevlâna Suleymân b. 'Abdirrahman elMaǵribî es-Semûnî ve Ta 'lîk 'alâ Hâş̧iyeti'l-Kürdî 'alâ Hâş̧iyeti Şerhi'l-ÂAâb adlı eserleri de tespit edilmiştir.

$\mathrm{Bu}$ eserlerine ek olarak az hacimli risale, fatva ve vaazlarına dair bilgilere de bu çalışmada yer verilmiştir. Diğer taraftan Mustafa Sıdkı Karabeg el-Mostarî (ö. 1878)'ye ait Hıdâdu'n-Nușûl adlı eserin Süleymaniye Ktp.de bulunan nüshasının kaynaklarda yanlışlıkla Eyyûbîzâde'ye nispet edildiği tespit edilerek bu yanlışlık düzeltilmiştir.

Ayrıca bu çalışma ile birkaç kaynak dışında bahsedilmeyen Eyyûbîzâde'nin Arap dili ve belagatına dair az hacimli üç risalesi incelenerek ve tahkik edilerek ilim dünyasının istifadesine kazandırılmıştır.

Bu risalelerden Risâle fì Beyâni İctimâ 'i'l-İsti'âreti'l-Tebe'iyye me'a't-Temsîliyye adlı ilk risale et-Teftâzânî ve el-Curcânî arasında Timur'un huzurunda gerçekleşen istiâre üzerine yapılan bir münazaranın konusu ele almaktadır. İkinci risale yine et-Teftâzânî ve el-Curcânî arasındaki ihtilaflı meselelerden biri olan inşâ cümlesi üzerinedir. Üçüncü risale ise elKuhistânî'nin iraba dair bazı açıklamalarına dairdir.

$\mathrm{Bu}$ kapsamda yaşadığı dönemde Osmanlı ilim çevrelerinin takdirini kazanmış Mustafa Eyyûbîzâde el-Mostarî tarafından uzun yıllar âlimler arasında ihtilafa neden olan meseleler üzerine te'lif edilmiş bu risalelerin tahkiklerinin yapılmasının Eyyûbîzâde'nin Arap dili ve belagatı üzerine yaptığı çalışmaların ortaya çıkarılması hususunda önemli bir katkı sunacağı aşikardır. 


\section{SUMMARY}

In this study, besides the information given about the life and the works of Ayyubizade, a critical edition and examination of Ayyubi-zade's three small volume epistles on Arabic language and rhetoric was done.

Mustafa Ayyubi-zade (Ejubovic) al-Mostari who was also known by his nickname Sheikh Jujo (Sejh Jujo) was the most fertile Bosnian scholar in Ottoman era with more than thity works composed on different fields and in three languages. He was born in Mostar in 1061/1651. After the elementary education he went to İstanbul to get higher education where he stayed 15 years. Then he returned to Mostar due to his appointment as mufti of Mostar. He lived there till his death in 1119/1707.

During the research of Ayyubi-zade's works for this study, some deficiencies and mistakes existing in sources related with works and manuscript copies of his works were detected. Thereby, it is aimed to correct these mistakes and deficiencies in this study.

Thus, in the first part of this study a comprehensive comparison of the information about the works and the manuscript copies of Ayyubi-zade's works located in different libraries, with comparing the information which was given by himself, his student Ibrahim Opijac al-Mostari, library catalogues, other sources and the mansucript copies of his works obtained from the libraries was made.

In this context, Ayyubi-zade gave a list of his 24 works in the first folio of his work Muntecabu'l-Husṣ̂ll fì Şerḥi Muntehabi'l-Uș̂ul located in Gazi Husrev Beg (GHB) Library $3858 / 1$.

Then, Ibrahim Opijac listed 27 works of his master in his work Risâle fî Menâkıııi'ş-Şeyh Yûyâ. According to this list, there is one work named Ta 'lị̂u Havâş̧ Şerhi Risâleti'l-Manțı li li'lFenârî which Ayyubi-zade listed but Opijac did not. And there are three more works named Şerḥ 'alấl-Luğati'l-Mevsûme bi'ş-Şâhidiyye (Hulla-i Manzûma), Şerḥu Risâle fì Âdâb li's-Seyyidi'şŞerîfi'l-Curcânî (Zubdetu'l-Âdâb), Şerḥu Dîbâceti'l-Muhtașari'l-Me 'ânî ve Nefâisi'l-Mecâlis fì'lMev 'iza which Opijac listed but Ayyubi-zade did not.

Besides these, there are works of Ayyubi-zade named Şerhu'l-'Avâmili'l-Mie, Hâş̧iyetu'lMuhtașar li Mevlâna Suleymân b. 'Abdirrahman el-Maġribî es-Semûnî ve Ta 'lị̂ 'alâ Hâş̧iyeti'lKürdî 'alâ Hâş̧iyeti Şerhi'l-Âdâb which Ayyubi-zade and his pupil Opijac did not list. Moreover, Ayyubi-zade has got small volume epistles, fatwas and preaches recorded in manuscripts.

On the other hand, a work named Hildâdu'n-Nușûl which is located in Süleymaniye Library Celal Ökten Collection nr. 131 and belongs to mufti of Mostar Mustafa Sidki Karabeg el-Mostari who was martyred at Austrian invasion of Bosnia in 1878 was referred mistakenly to Ayyubi-zade in library records and some sources.

In the second part, an examination and a critical edition of Ayyubi-zade's three small volume epistles was done which were composed on Arabic language and rhetoric. Besides Ayyubi-zade's works on Arabic grammer named Şerḩu Unmûżeci'z-Zemahşserî fín-Naḥv (elFevâidi'l-'Abdiyye) and Şerhu'l'-'Avâmili'l-Mie which some studies were made upon, these epistles had not been studied yet. While the first two of these epistles were mentioned in Muhamed Ždralovic's papers and GHB catalogs, third one had not been mentioned in any sources before. 
First epistle named Risâle fì Beyâni İctimâ 'i'l-İstiâreti'l-Tebeiyye me 'a't-Temsîliyye has got two manuscript copies of author located in Hrvatska Akademija Znanosti i Umjetnosti (HAZU) Library 1410/1 and GHB 4615/5. In critical edition the letter s was used for HAZU copy and $\dot{\varepsilon}$ was used for GHB as a symbol. It deals with the famous disputation that took place in presence of Amir Timur's between al-Taftazani (d. 792/1390) and al-Sharef al-Jurjani (d. 816/1413) on whether there exist al-istiare al-tabaiyya and al-istiare at-tamthiliyya at the

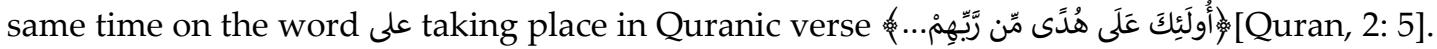
Ayyubi-zade in this epistle takes sides with al-Taftazani who claims its possibilty and discusses al-Jurjani's explanations.

Second epistle named Risâle fì Kevni'l-Cumle Muțlakan Haberan li'l-Mubteda' has two manuscript copies. Author's copy is located in HAZU 1410/2 and the other copy is located in GHB 4611/2. In critical edition, the letter 5 was used for HAZU copy and $\dot{\varepsilon}$ was used for GHB as a symbol. It deals with another dispute between al-Taftazani and al-Jurjani about the permissibility of insha sentence as knowledge without interpretation (ta'weel). Ayyubi-zade in this epistle takes sides with al-Taftazani and other scholars who claim its permissibility

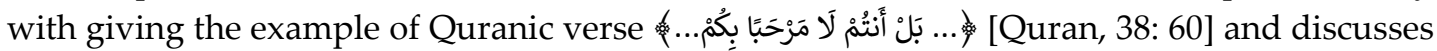
the explanations of al-Jurjani and other scholars explanations who are againts this permissibility.

Third epistle named Risâle fì mâ Kâle el-Kuhistânî 'an I'râbi 'íbareti "Kitâbi'ț-Ṭahâre" has only one manuscript copy which is the author's copy located in HAZU 1410/3. In critical edition, the letter 5 was used for the copy as a symbol. It deals with possible declensions of the phrase of "Kitab al-Tahara" taking place in the commentary work named Jami" alRumuz Sharh Mukhtasar al-Wiqaya belonging to Shamsaddeen al-Quhistani (d. 962/1555). Then Ayyubi-zade made a syntactic analysis of these possibilities.

\section{Makale Bilgileri}

\begin{tabular}{|c|c|}
\hline Etik Kurul Kararı: & Etik Kurul Kararından muaftır. \\
\hline Katılımcı Rızası: & Katılımc1 yoktur \\
\hline Mali Destek: & Çalışma için herhangi bir kurum ve projeden mali destek alınmamıştır. \\
\hline Çıkar Çatışması: & Çalışmada kişiler ve kurumlar arası çıkar çatışması bulunmamaktadır. \\
\hline Telif Hakları: & $\begin{array}{l}\text { Çalışmada kullanılan görsellerle ilgili telif hakkı sahiplerinden gerekli } \\
\text { izinler alınmıştır. }\end{array}$ \\
\hline \multicolumn{2}{|l|}{ Article Information } \\
\hline Ethics Committee Approval: & Exempt from the Ethics Committee Decision. \\
\hline Informed Consent: & No participant \\
\hline Financial Support: & No financial support from any institution or project. \\
\hline Conflict of Interest: & No conflict of interest. \\
\hline Copyrights: & $\begin{array}{l}\text { The required permissions have been obtained from the copyright } \\
\text { holders for the images and photos used in the study. }\end{array}$ \\
\hline
\end{tabular}




\section{KAYNAKÇA}

Abdelaal, F. E. B. (2017). Haşiye ala şerhi miftahu'l-ulum li's-Seyyidi'ş-Şerif adlı eserinin tahkiki (Yayımlanmamış yüksek lisans tezi). Selçuk Üniversitesi, Konya.

Bašagić, Safvet-beg (1986). Bošnjaci i Hercegovci u Islamskoj književnosti. Saraybosna: Svjetlost Yay.

Bolelli, N. (2016). Belagat (beyan-me'ani-bedi` ilimleri) Arap edebiyatı. İstanbul: M. Ü. İlahiyat Vakfı Yay.

Brockelmann, C. (1937). Geschichte der Arabischen litteratur (C. Sup. I). Leiden: Brill Yay.

Bursalı, M. T. (1333/1914-15). Osmanlı müellifleri (C. 2). İstanbul: Matbaa-i Âmire.

Câmi'u'l-Mahtutâti'l-İslamiyye (CMİ) (t.y.). Bernâmecu'l-bâhis fi'l-mahtutâti'l-i̇slâmiyye. https://wqf.me/ Erişim Tarihi: 02.02.2020.

Ćeman, M. (2011). Mustafa Ejubović, Šejh Jujo; bibliografija. Mostar: Muzej Hercegovine Yay.

Çelebî, K. (1941). Keşfu'z-zunûn (C. 1-2). (Ş. Yaltkaya \& R. B. Kilisli, Haz.). İstanbul: Maarif Matbaasi.

Çelik, Y. (2009). es-Seyyid eş-Şerîf el-Cürcani'nin "el-misbah fi şerh el-miftah" adlı eserinin tahkik ve tahlili (edisyon kritik) (Doktora tezi). Erişim Adresi: https://tez.yok.gov.tr/UlusalTezMerkezi/

Dobrača, K. (2002). Katalog Arapskih, Turskih, Perzijskih i Bosanskih rukopisa / Gazi HusrevBegova biblioteka (C. 2). Londra: al-Furqan Fondacija za Islamsko Naslijeđe; Saraybosna: Rijaset Islamske Zajednice u Bosni i Hercegovini Yay.

el-Âlûsî, Ş. (1314/1896-97). el-Ecvibetu'l-Irâkiyye ani'l-esileti'l-İrâniyye (Ali Dede el-Bosnevî́nin havatimu'l-hikem el-musemma bi halli'r-rumuz adlı eserin hamişinde basılmış olarak). Kahire: Matbaa-i Osmaniye.

el-Âlûsî, Ş. (1353/1934-35). Ruhu'l-Meânî (C. 1). Beyrut: İdâretu't-Tıbâati'l-Munîriyye-Daru'1İhyâi't-Turâsi'l-Arabiyyi Yay.

el-Babertî, E. Hâş̧iye ala'l-keşşâf. Köprülü Kütüphanesi. Fazıl Ahmed Paşa Koleksiyonu, 194.

Elbera, E. (2019). Musannifek'in haşiye 'ale'l-mutavvel adlı eserinin tahkiki (C. 4.) (Yüksek lisans tezi). Erişim Adresi: https://tez.yok.gov.tr/UlusalTezMerkezi/

el-Câhiz (1998). el-Beyân ve't-tebyîn (7. bs.) (C. 1-4). (A. M. Hârûn, Tah.). Kahire: Mektebetu'1Cahiz Yay.

el-Curcânî, S. Ş. (2007). Hâşiye ale'l-mutavvel. (R. Aridî, Haz.). Beyrut: Dâru'l-Kutubi'l-İlmiyye Yay.

el-Hâşimî, A. (1999). Cevâhiru'l-belâga. (Y. es-Sameylî, Haz.). Beyrut: Mektebetu'l-Asriyye Yay.

el-İsferayinî, I. (1313/1895). Şerhu'l-kâfiye. İstanbul: Matbaa Daru's-Saltane.

el-Kazvinî, C. (2003). el-Îdâh fî ulûmi'l-belâga. (İ. Şemseddin, Haz.). Beyrut: Daru'l-Kutubi'lİlmiyye Yay.

el-Kuhistânî, Ş. M. (1858). Câmi 'u'r-rumûz şerhi muhtasari'l-vikâye el-musemma bi'n-nukâye. (K. Ahmed, Haz.). Kalküta: Matbaa Mazhari'l-Acâib Yay.

el-Mostarî, M. S. K. (1316/1898). Hıdâdu'n-nusûl ala mirâti'l-usûl. Saraybosna: Državna Štamparija Yay.

el-Murâdî, M. (1301/1883-84). Silku'd-durer (C. 6). Bağdat: Mektebetu'l-Musenna Yay.

el-Yemenî, Y. K. Tuhfetu'l-eşraf fi keşfi gavamidi'l-keşşaf. el-Melik Suûd Üniversitesi Kütüphanesi, 2135.

er-Radî, E. (1993). Şerhu'l-kafiye (C. 1-2). (Y. B. Misrî, Tah.). Kahire: Hicr li't-T1bâa ve'n-Neşr ve't-Tevzi“ ve'l-ïlan Yay.

es-Sekkâkî, S. (1987). Miftâhu'l-ulûm. (N. Zerzur, Haz.). Beyrut: Daru'l-Kutubi'l-İlmiyye Yay. es-Siyâlkûtî, A. (1404/1983-84). Haşiye ale'l-mutavvel (2. bs.). Kum: Menşurati'r-Rıza Yay. 
et-Teftâzânî (2013). el-Mutavvel (3. bs.). (H. Hindâvî, Tah.). Beyrut: Daru'l-Kutubi'l-İlmiyye Yay.

et-Teftâzânî. Haşiye ala'l-keşşaf. Köprülü Kütüphanesi. Fazıl Ahmet Paşa Koleksiyonu, 190.

et-Teftâzânî. Şerhu'l-miftâh. Milli Kütüphane, 06 Mil Yz FB 48.

et-Tehânevî, M. A. (1996). Keşşâf ıstılahi'l-funûn ve'l-ulûm. (R. el-Acem \& A. Dehruc, Tah.). Lübnan: Mektebe Lubnan Yay.

et-Tîbî, Ş. (2013). Futûhu'l-gayb (C. 2). (Ö. H. el-Kıyâm, Tah.). Abu Dabi: Câize Dabî edDuveliyye li'l-Kur'âni'l-Kerim Yay.

Eyyûbîzâde, M. Miftâhu'l-husûl li mirâti'l-usûl fî şerhi mirkâti'l-vusûl. Gazi Husrev Begova Kütüphanesi. 3871.

Eyyûbîzâde, M. Muntecabu'l-husûl fì şerhi muntehabi'l-usûl. Gazi Husrev Begova Kütüphanesi. 3858/1.

Eyyûbîzâde, M. Şerhu risâle fî âdâb li's-Seyyidi'ş-Şerîfi'l-Curcânî. Gazi Husrev Begova Kütüphanesi. 4871/2.

Eyyûbîzâde, M. Şerhu risâleti'l-ferâ'id. Gazi Husrev Begova Kütüphanesi. 3860.

Eyyûbîzâde, M. Şerhu tehzîbi'l-mantık ve'l-kelâm. Orijentalni Institut u Sarajevu Kütüphanesi. 23.

ez-Zemahşerî (2009). el-Keşşâf. (H. H. Şihâ, Haz.). Beyrut: Daru'l-Mearif Yay.

Fajić, Z. (1991). Katalog Arapskih, Turskih, Perzijskih i Bosanskih rukopisa / Gazi Husrev-Begova biblioteka (C. 3). Londra: al-Furqan Fondacija za Islamsko Naslijeđe; Saraybosna: Rijaset Islamske Zajednice u Bosni i Hercegovini Yay.

Fajić, Z. (1999). Katalog Arapskih, Turskih, Perzijskih i Bosanskih rukopisa / Gazi Husrev-Begova biblioteka (C. 5). Londra: al-Furqan Fondacija za Islamsko Naslijeđe; Saraybosna: Rijaset Islamske Zajednice u Bosni i Hercegovini Yay.

Fajić, Z. (2003). Katalog Arapskih, Turskih, Perzijskih i Bosanskih rukopisa / Gazi Husrev-Begova biblioteka (C. 11). Londra: al-Furqan Fondacija za Islamsko Naslijeđe; Saraybosna: Rijaset Islamske Zajednice u Bosni i Hercegovini Yay.

Gazić, L. (2009). Katalog Arapskih, Turskih, Perzijskih i Bosanskih rukopisa, orijentalni institut u Sarajevu. Londra: al-Furqan Fondacija za Islamsko Naslijeđe; Saraybosna: Institut for Orijental Studies Yay.

Görgün, T. (2000). İnşâ. DİA (C. 22, s. 339-341). İstanbul: Diyanet Vakfı Yay.

Handžić, M. (1934). Nekoliko dragocjenih rukopisa u Karađozbegovoj biblioteci u Mostaru. Glasnik Vrhounog Starješinstva Islamske Vjerske Zajednice, 2(12), 633-639.

Handžić, M. (1992). el-Cevher el-esna fi teracimi ulemai ve şuerai Bosna. (A. M. el-Hılv, Tah.). Kahire: Mektebetu Hicr Yay.

Hasandedić, H. (1974). Djela Mustafe Ejubovica (Sejh Juje) i Ibrâhîm Efendije Opijaca koja se nalaze u arhivu Hercegovine u Mostaru. Anali GHB, 4, 57-68.

Hasandedić, H. (1982). Nekoliko rukopisa iz orijentalne zbirke provincijalata Hercegovačkih franjevaca u Mostaru. Anali GHB, 7-8, 161-176.

Hasandedić, H. (2005). Spomenici kulture Turskog doba u Mostaru. Mostar: Islamski Kulturni Centar Yay.

Institute of Oriental Manuscripts in Saint Petersburg (IOM) (t.y.). Arabic manuscripts of the Institute of Oriental Studies, short catalog. A.B. Khalidova (Ed.). http://www.orientalstudies.ru/eng/index.php?option=com_publications\&Itemid=75\&pu b=73 Erişim Tarihi: 05.02.2020.

İbn Hişam, C. (1991). Mugnîll-lebîb (C. 1-2). (M. M. Abdulhamid, Tah.). Beyrut: elMektebetu'l-Misriyye Yay.

İbn Kuteybe (1981). Edebu'l-kâtib. (M. ed-Dâlî, Tah.). Beyrut: Muessetu'r-Risale Yay. 
İbn Malik, C. (1967). Teshilu'l-fevâid ve tekmilu'l-mekâsıd. (M. K. Berekât, Tah.). Kahire: Dâru'lKitabi'l-Arabî Yay.

İbnu'l-Hacib (2010). el-Kafiye ve'l-şafiye. (S. A. eş-Şair, Tah.). Kahire: Mektebetu'l-Adâb Yay.

Jahić, M. (1985). Rukopisi djela Šejh Juje u Gazi Husrevbegovoj biblioteci. Anali GHB, 11-12, 39-53.

Jahić, M. (1999). Katalog Arapskih, Turskih, Perzijskih i Bosanskih rukopisa/Gazi Husrev-Begova biblioteka (C. 6). Londra: al-Furqan Fondacija za Islamsko Naslijeđe; Saraybosna: Rijaset Islamske Zajednice u Bosni i Hercegovini Yay.

Jahić, M. (2013). Katalog Arapskih, Turskih, Perzijskih i Bosanskih rukopisa / Gazi Husrev-Begova biblioteka (C. 18). Londra: al-Furqan Fondacija za Islamsko Naslijeđe; Saraybosna: Rijaset Islamske Zajednice u Bosni i Hercegovini Yay.

Karol, P. \& Blaškovič, J. (1960). Arabske, Turecke A Perzske rukopisy univerzitnej knižnice (ayribasım "Univerzitna knižnica v Bratislave 1919-1959 vydala Matica Slovenska Martin 1959" adlı kitabin 125.-145. sayfalarindan). у.у.

Merkezu'1-Meliki Faysal (MKF) (t.y.). Hizânetu't-turâs-fihrisu mahtûtât. http://shamela.ws/index.php/book/5678 Erişim Tarihi: 30.01.2020.

Mestcizade, A. E. (1278/1861). İhtilafu's-Seyyid ve's-Sadeddin. İstanbul: Matbaatu Mektebeti'1Harbiyyeti's-Sultaniye.

Molla Cami, N. A. (2014). el-Fevaidu'd-diyaiyye. (İ. Kaplan, Haz.). Beyrut: Daru'1-Kutubi'1İlmiyye Yay.

Nametak, A. (1992). Ramazanske price. (5. bs.). Saraybosna: Kaligraf Yay.

Nametak, F. \& Trako, S. (1997). Arapskih, Perzijskih, Turskih i Bosanskih rukopisa iz zbirke Bošnjačkog instituta (C. 1). Zurih: Bošnjački Institut Yay.

Opijač, İ. Risâle fì menâkibi'ş-Şeyh Yuyâ Mustafâ b. Yûsuf el-Mostârî. Gazi Husrev Begova Kütüphanesi, 3858.

Özen, Ş. (2011). Teftazani. DIA (C. 40, s. 299-308). İstanbul: Diyanet Vakf1 Yay.

Pala, İ. \& Durmuş, İ. (2001). İstiare. DİA (C. 23, s. 315-318). İstanbul: Diyanet Vakfı Yay.

Popara, H. \& Fajić, Z. (2000). Katalog Arapskih, Turskih, Perzijskih i Bosanskih rukopisa / Gazi Husrev-Begova biblioteka (C. 7). Londra: al-Furqan Fondacija za Islamsko Naslijeđe; Saraybosna: Rijaset Islamske Zajednice u Bosni i Hercegovini Yay.

Popara, H. (2008). Katalog Arapskih, Turskih, Perzijskih i Bosanskih rukopisa / Gazi Husrev-Begova biblioteka (C. 16). Londra: al-Furqan Fondacija za Islamsko Naslijeđe; Saraybosna: Rijaset Islamske Zajednice u Bosni i Hercegovini Yay.

Popara, H. (2010). Ocjeni i prikazi-historijski arhiv Sarajevo-katalog Arapskih, Turskih, Perzijskih i Bosanskih rukopisa-Mustafa Jahić. Anali GHB, 39(31), 311-314.

Šabanović, H. (1960). Mustafa b. Yusuf Aiyubi al-Mostari-biobibliografska skica. Prilozi za Orijentalni Filologiju, 8-9, 29-35.

Šabanović, H. (1973). Knjižeonost Bosanskih Muslimana na orijentalnim jezicima. Saraybosna: Svjetlost Yay.

Trako, S. \& Gazić, L. (1997). Katalog rukopisa orijenatlnog instituta-ljepa knjižeonost. Saraybosna: Orijentalni Institut u Sarajevu Yay.

Udovćić, S. (1900-1901). Šehjuj efendija. Behar, 1, 254.

Univerzitna Knižnica $\mathrm{v}$ Bratislave (UKB) (t.y.). Katalog. https://chamoukb.kis3g.sk/search/query?theme=ukb Erişim Tarihi: 13.01.2020.

Ždralović, M. (1981). Prilog poznavanju djela Šejha Juje. Hercegovine, 1, 119-137.

Ždralović, M. (2002). Gramatičar Šejh Jujo i Mostarska tradicija učenja Araspkog jezika (od XVI. do druge polovice XIX. stoljeća). Mudrost rađa toleranciju, naučni skup povodom 350 godina od rođenja Mustafe Ejubovića- Šejh Juje i 400 godina predavanja "mesnevije" u Mostaru içinde (37-52). Mostar. Centar za Kulturu Yay.

SEFAD, 2020; (44): 131-160 


\section{EKLER:}

Ek-1: HAZU Ktp. nr. 1410 vr. 1b-2a: Risâle fî Beyâni İctimâ'i'l-İsti’âre, ilk varak

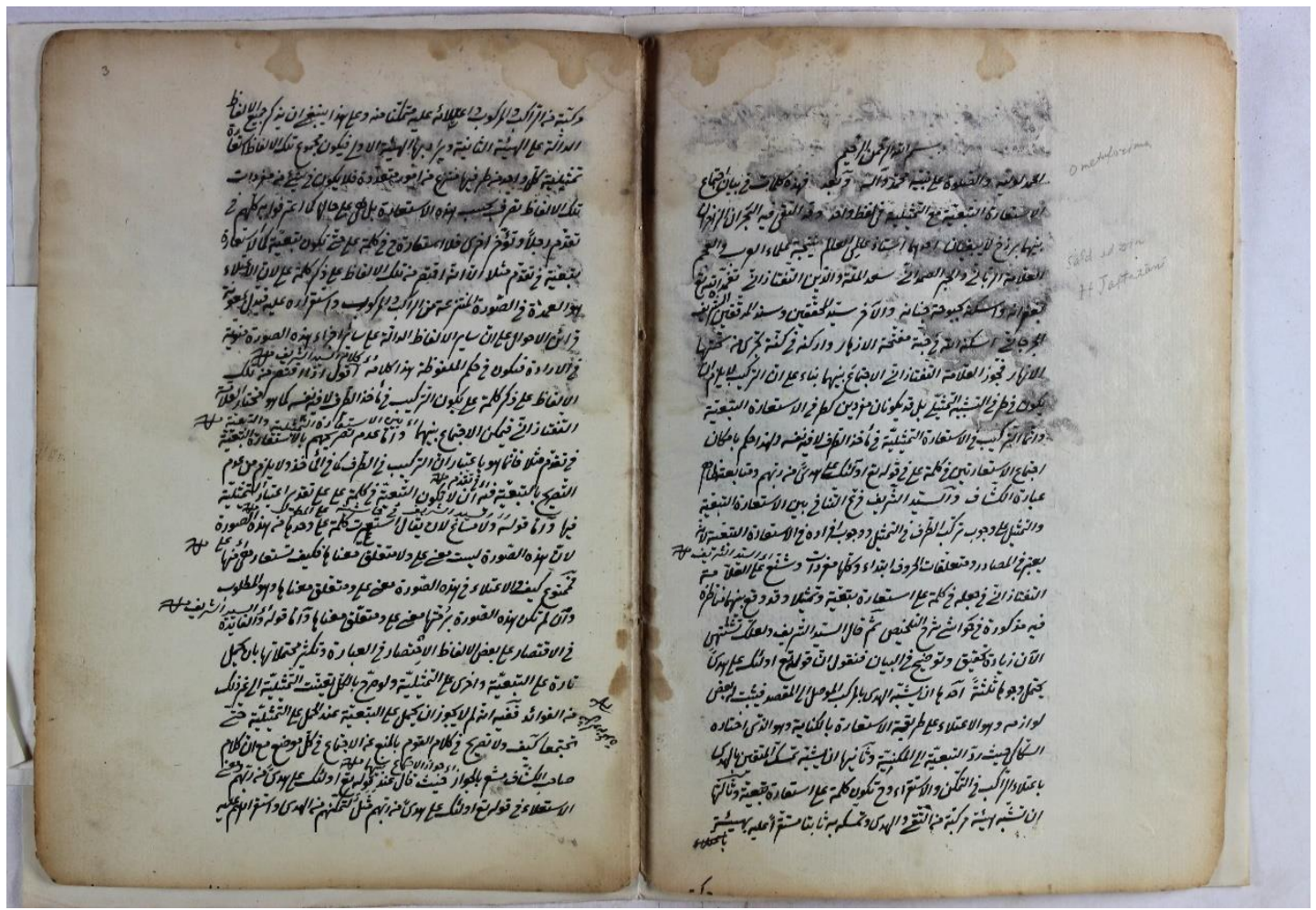

Ek-2: HAZU Ktp. nr. 1410 vr. 2b: Risâle fî Beyâni İctimâ'i'1- İsti’âre, son varak / 3a: Risâle fî Kevni'1-Cumle, ilk varak

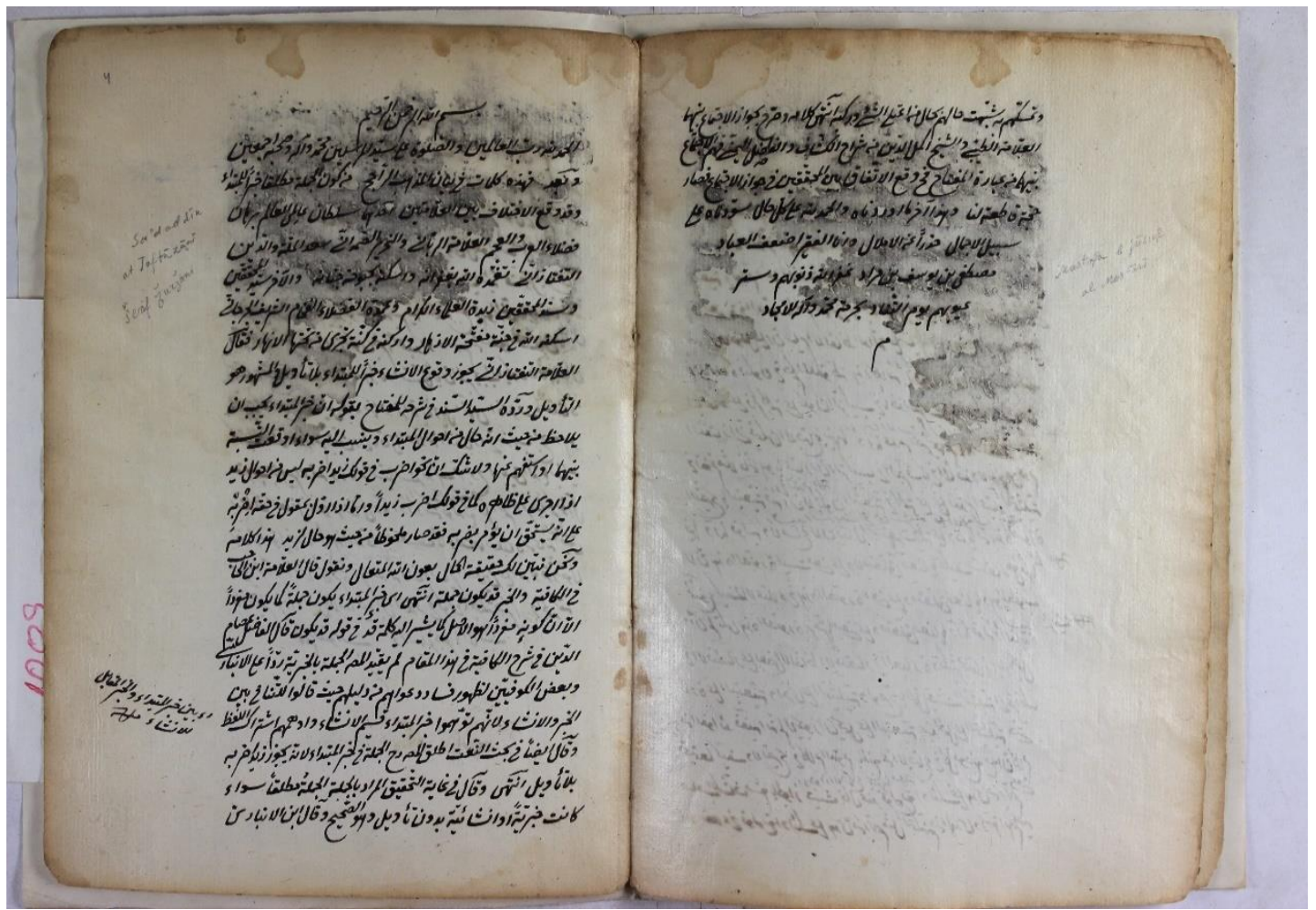


Ek-3: HAZU Ktp. nr. 1410 vr. 3b: Risâle fî Kevni'l-Cumle, son varak / 4a: Risâle fî mâ Kâle elKuhistânî, ilk varak

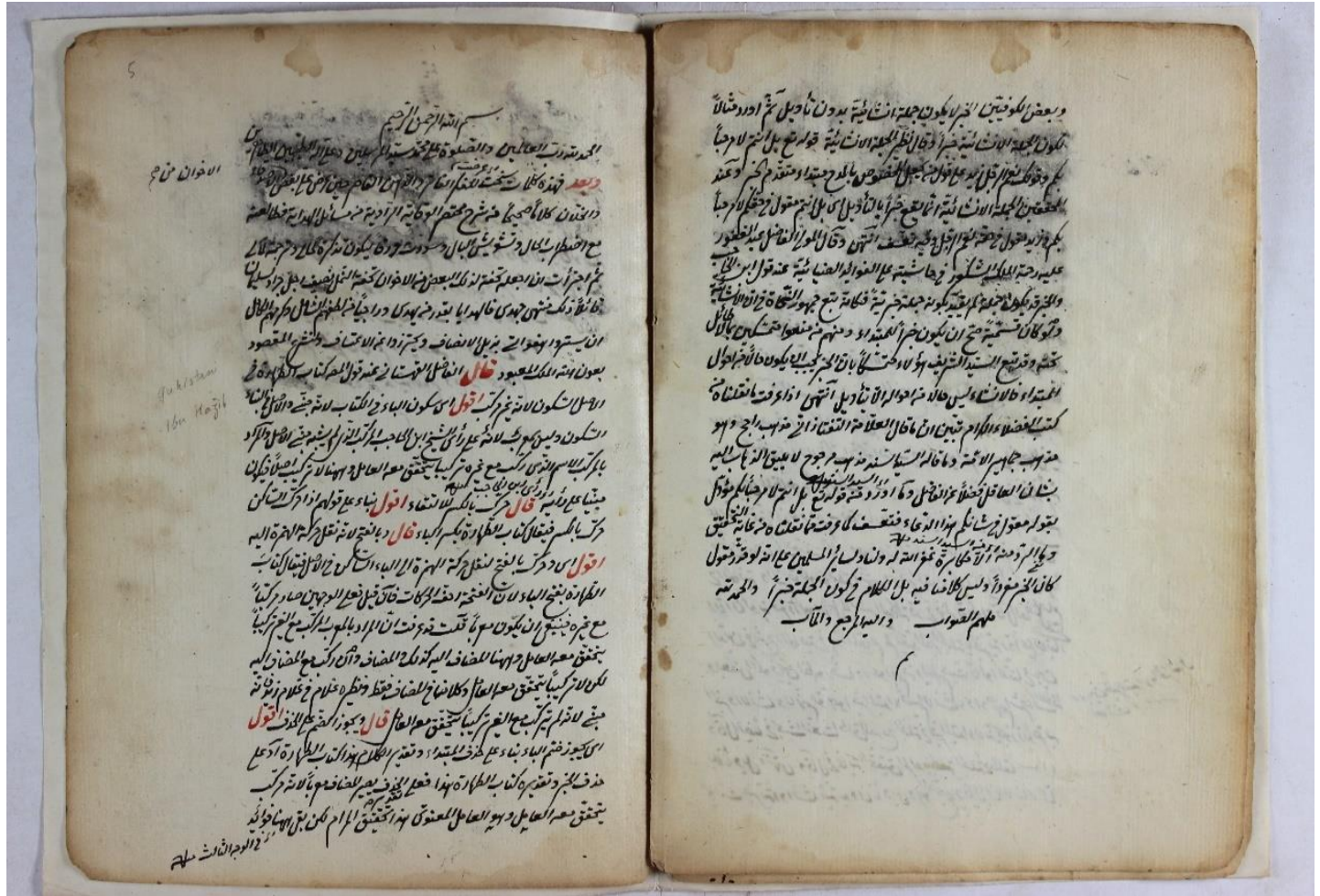

Ek-4: HAZU Ktp. nr. 1410 vr. 4b: Risâle fî mâ Ḳâle el-Ḳuhistânî, son varak

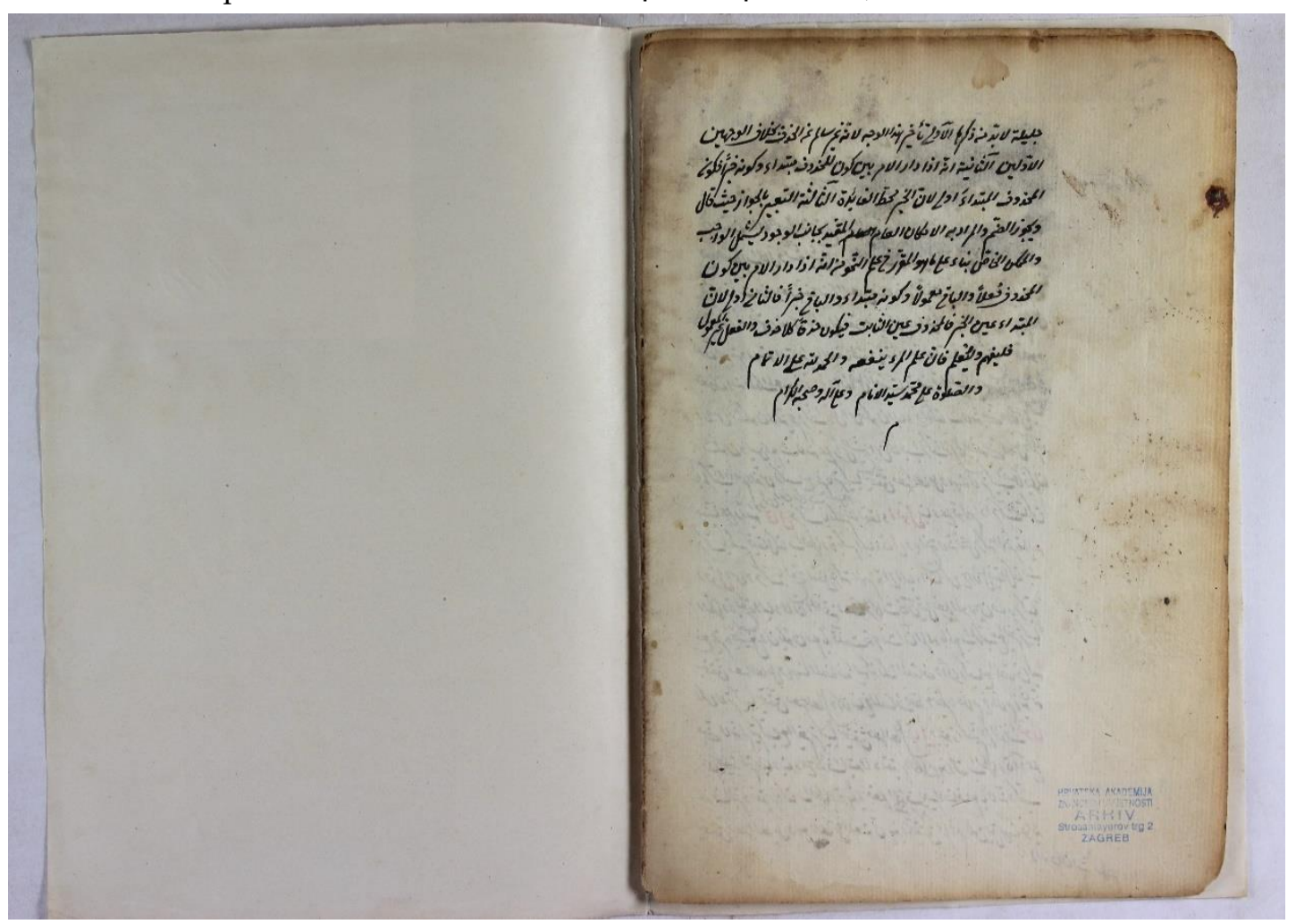


Ek-5: GHB Ktp. nr. 4615/5 vr. 17b: Risâle fî Beyâni İctimâ'i'l- İsti’âre, ilk varak

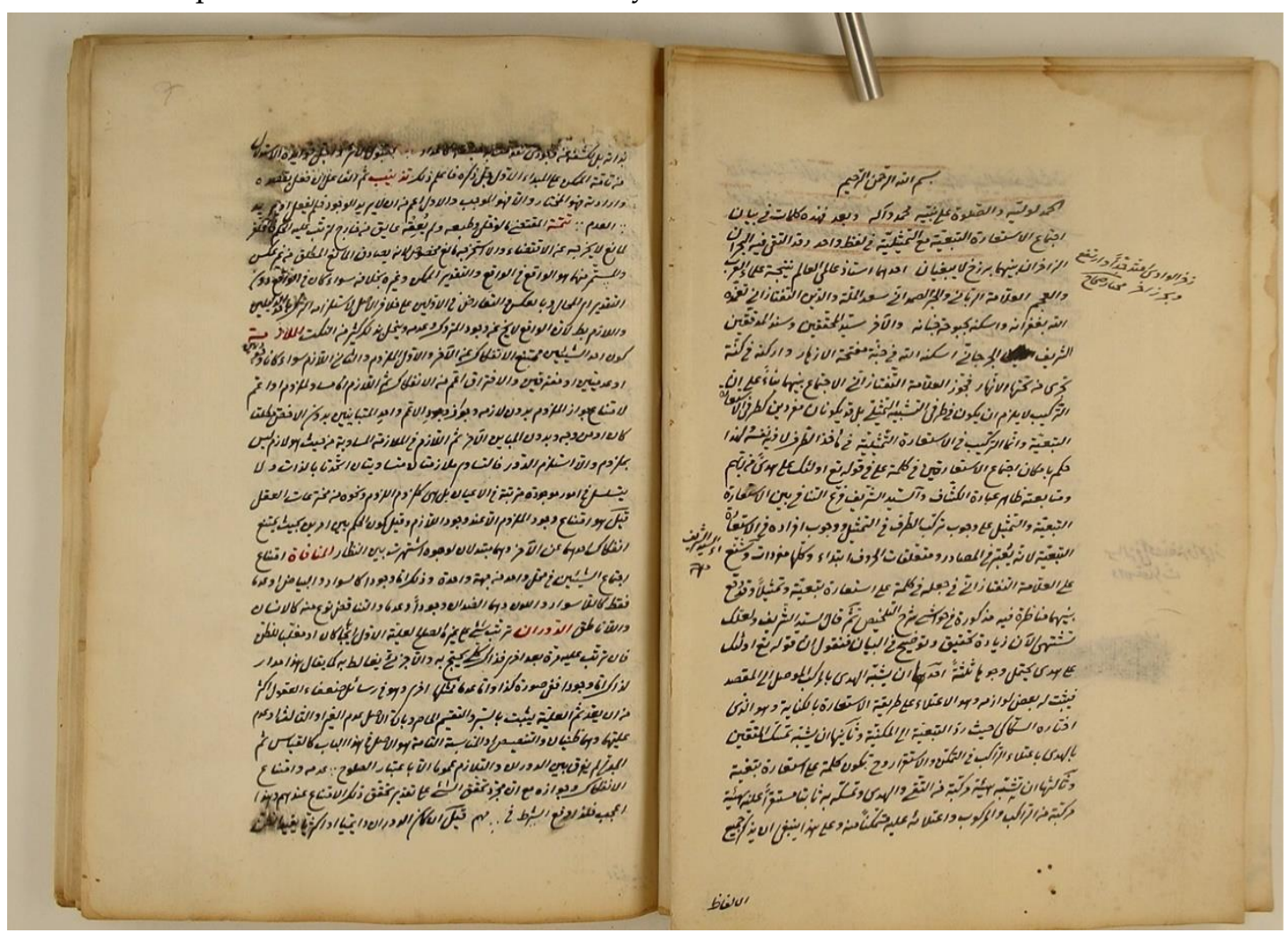

Ek-6: GHB Ktp. nr. 4611/2 vr. 211b-212a: Risâle fî Kevni'l-Cumle, ilk ve son varak

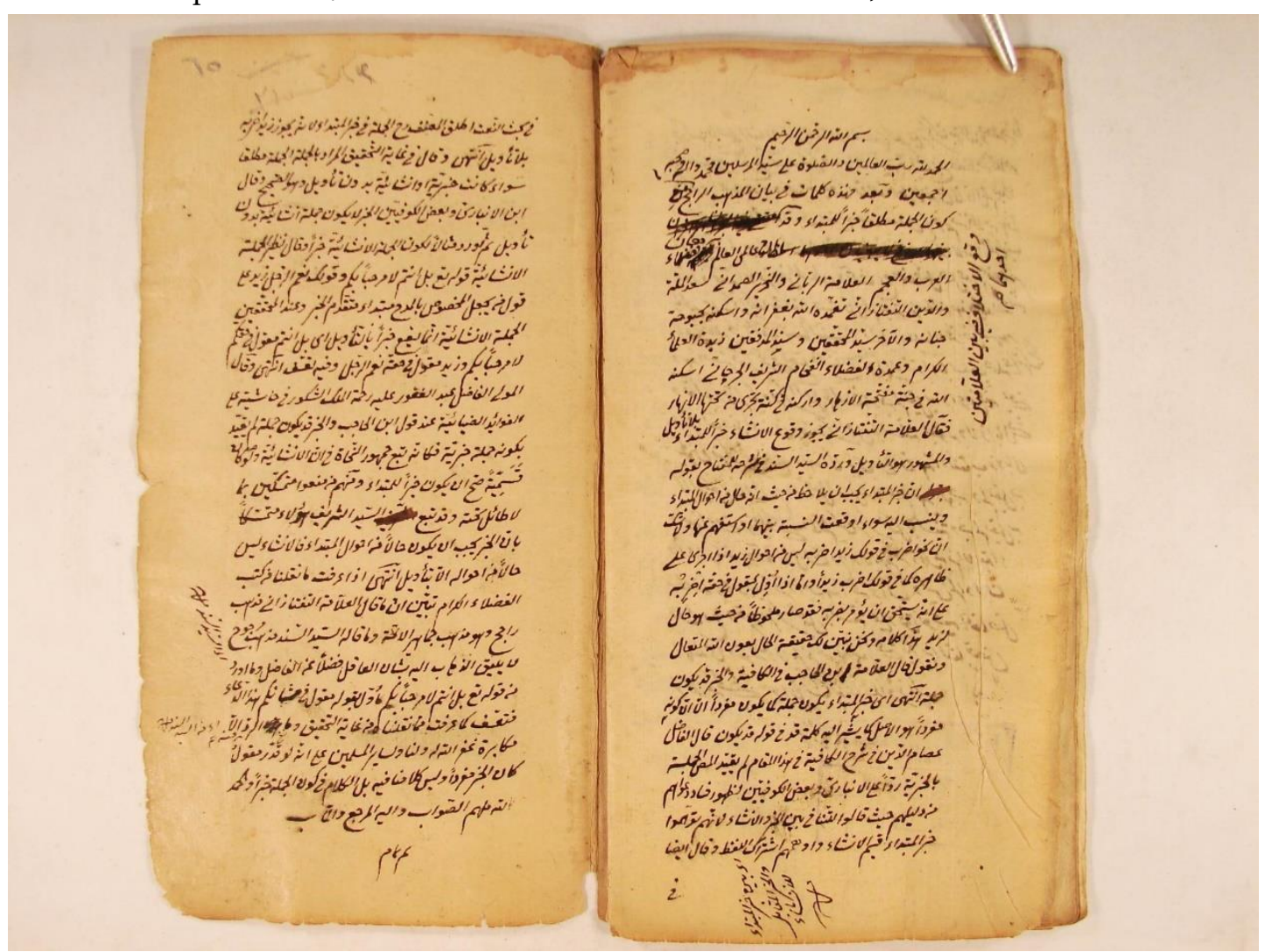

